\title{
Öğretmen Adaylarının Öğrenme Öğretme Anlayış Düzeyleri İle Metaforik Algılarının İncelenmesi
}

\author{
Nurhak Cem DEDEBALİ*, Serhat SÜRAL ${ }^{* *}$
}

- Geliş Tarihi: 04.01.2021 • Kabul Tarihi: 01.07.2021 • Çevrimiçi Yayın Tarihi: 01.07.2021

\section{$\ddot{\mathbf{O} z}$}

Öğretmen adaylarının edindiği yaşantılar başta olmak üzere, öz yeterlikleri, dünyaya ve eğitime olan bakış açıları, bireysel farklılıkları dikkate alınarak öğrenme öğretme anlayışlarının ne yönde şekillendiği ölçülüp, yapılandırmacı eğitim anlayışını kendi bakış açılarına göre metaforlar üretmeleri ve böylece bu konudaki genel algılarının görülmeye çalışılması amaçlanmıştır. Çalışmada, nicel ve nitel veri toplama yöntemleri kullanarak bulgu ve sonuçların bir çerçeve içerisinde sunulmasına, analiz edilmesine ve bir araya getirilmesine imkân tanıyan karma yöntem kullanılmıştır. Çalışma 2019-2020 eğitim öğretim yılında Türkiye'nin farklı bölgelerindeki üniversitelerinde öğrenim gören Sınıf öğretmenliği, İngilizce, Türkçe, Matematik, Fen Bilgisi, Müzik öğretmenliğinden toplam 284 öğretmen adayıyla gerçekleştirilmiştir. Araştırma kapsamında öğretmen adaylarının öğrenme öğretme anlayışlarını belirlemek için Chan ve Elliot (2004) tarafından geliştirilen Öğretme ve Öğrenme Anlayışları Ölçeği kullanılmıştır. Araştırmanın sonunda hayatı kolaylaştırıcı, mesleki ve insani roller, doğanın sundukları, faydalı eşya ve organizmada bulunanlar metafor kategorilerine ulaşılmıştır.

Anahtar sözcükler: Yapılandırmacı1ık, geleneksel anlayış, metafor, öğretmen adayı

Atıf:

Dedebali, N.C. ve Süral, S. (2022). Öğretmen adaylarının öğrenme öğretme anlayış düzeyleri ile metaforik algılarının incelenmesi. Pamukkale Üniversitesi Ĕ̈itim Fakültesi Dergisi, 54, 158187.doi:10.9779.pauefd. 853592

\footnotetext{
* Doç. Dr., İzmir Katip Çelebi Üniversitesi, dedebali40@hotmail.com

** Doç. Dr., Pamukkale Üniversitesi, serhatsural@gmail.com
} 


\section{Giriş}

Toplumun, bireyin, konu alanın ihtiyaçlarından yola çıkıp, belli eğitim süzgeçlerinden geçirilerek sentezlenen hedeflerin, öğretim programlarına kazanımlar halinde yerleştirilmesi program geliştirme sürecinin önemli bir bölümünü oluşturduğu bilinen bir gerçek olmasına rağmen, daha önemli olanın belirlenen bu kazanımların birey üzerinde davranışa nasıl dönüştürüleceğidir. Çünkü birey üzerinde kalıcı izli bir davranış değişikliği oluşturabilmek, öğrenilmiş davranışı ortaya çıkarabilmektedir. Edinilen bilgilerin yaşantılar yoluyla davranışa dönüşmesi ile birlikte, yapılandırmacı anlayış bu davranışların bireyin günlük hayatındaki işlevselliğini merkeze almaktadır. Yapılandırmacı anlayışın da etkilendiği pragmatist görüş, doğru bilginin bireye fayda sağlayan bilgi olduğu şeklinde (Bakır, 2006; Değirmencioğlu, 2000; Kazu, 2002), bilgiyi tanımlıyor olması bilginin beceriye dönüşmesi gerektiğini bir kez daha vurgulamaktadır.

Öğrenenlerin bilgiyi nasıl öğrendiklerine ilişkin bir kuram olarak gelişmeye başlayan yapılandırmacılık zamanla öğrenenlerin bilgiyi nasıl yapılandırdıklarına ilişkin bir yaklaşım halini almıştır. Yapılandırmacılıkta bilginin tekrarı değil, bilginin transferi ve yeniden yapılandırılması söz konusudur (Perkins, 1999). Yapılandırmacı anlayış ile birlikte bireylerden, bilgi tüketmekten çok bilgi üretmeleri beklenmektedir. Çağdaş dünyanın kabul ettiği birey, kendisine aktarılan bilgileri aynen kabul eden, yönlendirilmeyi ve biçimlendirilmeyi bekleyen değil, bilgiyi yorumlayarak anlamın yaratılması sürecine etkin olarak katılanlardır (Yıldırım ve Şimşek, 1999). Farklı bilim insanlarının da belirttiği gibi, bilginin sadece hazır olarak aktarıldığı, öğrencinin çok fazla etkin kılınmadığı geleneksel öğrenme ortamlarının çağdaş eğitim anlayışı içerisinde artık kabul edilebilir bir durum olmadığ1 söylenebilirken; öğrenciye problem çözme becerisini öğreterek, onlara üst düzey düşünme becerilerini kazandırmayı amaçlayan yapılandırmacı eğitim anlayışı 21. yy. eğitim anlayışını çok daha iyi yansıtmaktadır. Yurdakul'a (2005) göre yapılandırmacı anlayışta öğrenme, daha çok anlam oluşturma olarak görülmekte anlamın ise gerçekliğin etkisi altında ya da doğrudan öğretimle değil, öğrenen tarafindan oluştuğu iddia edilmektedir. Benzer şekilde Akar ve Yıldırım (2004) yapılandırmacı anlayışı, öğrencinin sınıf içinde ya da dışında aktif katılımını gerektirdiğini, öğrenme sürecinde öğrencinin sorumluluk almasını ve karar verme sürecine katılmasının önemini algıladığını ve bireyin öğrenirken geçmişten gelen deneyim ve bilgilerini, karşılıklı konuşma ve yansıtma yöntemiyle paylaşarak yeni bilgileri oluşturduğunu söylemişlerdir. Siebert (2005) ise, yaşamda ilerlerken sosyal değişimlerle birlikte akla uygunlukla ilgili algılama da değişikliğe uğradığını, bu nedenle 
yapılandırmacılıkta kesin bir öğrenme yerine, esnek, geliştirilebilir ve eleştirel bir öğrenme anlayışı bulunduğunu ifade etmiştir. Yapılandırmacı öğretim sürecinde, öğretmene süreci düzenleme, yönlendirme ve rehberlik rolleri verilirken, öğrenmenin sorumluluğu büyük ölçüde öğrenciye (öğretmenle birlikte) verilmiştir. Bu bakımdan yapılandırmacı öğrenme, öğrencinin kendi yetenekleri, güdüleri, tutumu ve tecrübelerinden edindikleri ile oluşan bir karar verme sürecidir (Şaşan, 2002). Geleneksel anlayışın getirdiği öğretmen merkezli öğretimin yerine öğrenci merkezli öğretimin yer bulduğu yapılandırmacı anlayışın temelinde, daha önemli olan öğretmen öğrenci etkileşimini güçlendirmek yatmaktadır. Bilinmelidir ki; sınıf ortamını organize eden, tasarlayan ve uygulayan öğretmendir. Marlowe ve Page'in (2005) de ifade ettikleri gibi yapılandırmacı sınıflarda öğretmen; kendi gelişimlerini izlemeleri, öğrenme ve nitelikli çalışma için ölçüt hazırlamaları ve kendilerini geliştirici plan hazırlamaları için öğrenenlere yardımcı olmalıdır. Aydın (2007) yapılandırmacı bir öğretmeni geleneksel öğretmenden ayırt ederken çağdaş eğitim anlayışındaki öğretmeni, öğretmeye teşvik eden bir rehber, öğrenmede deneyim ve ön bilgilerin önemini bilen, ezber gerektiren bilgiler aktarmak yerine, yaratıcı, eleştirel ve analitik düşünmeyi merkeze alan öğrenme öğretme ortamlarını yaratan kişi olarak tanımlamaktadır.

Yapılandırmacı öğrenmede öğretmen; bilgiyi oluşturma sürecinde öğrenciye rehberlik edip, öğrenciyi araştırma incelemeye teşvik eder. Öğrenme durumlarında öğrencilerin bireysel farklılıklarını dikkate alarak uygun bir ortam hazırlar. Öğrencilerin hipotez kurma ve farklı yorumlar yapabilme yeteneklerini destekleyerek bilgiyi yeniden yapılandırmalarına olanak sağlar. Öğretmenlerin yapılandırmacı öğretmene ilişkin bakış açıları; başka bir ifade ile yapılandırmacı öğretmene ilişkin duyuşsal özellikleri öğretim uygulamalarını dolaylı olarak etkileyecektir (Küçüktepe ve Gürültü, 2014). Geleneksel eğitim anlayışında öğretmenin öğrencilerin duyuşsal özelliklerini dikkate almaması, onların duyuşsal yönde geliştirebilecekleri giriş davranışlarını önemsemeden derse başlaması, öğrencilerin derse karşı motivasyonunu olumsuz yönde etkilediğini ortaya koyarken, yapılandırmacı anlayış tam bu noktada öğrencilere bir bütün olarak bakılması gerektiğgini savunmaktadır. $\mathrm{Bu}$ düşünceyle birlikte, öğretmen öğretimi gerçekleştirirken öğrencilerin süreç içerisindeki gelişimini de takip ederek tümel bir değerlendirmeyi planlamaya başlamıştır.

Demirel (2008), yapılandırmacı öğretmeni açık fikirli, çağdaş, kendini yenileyebilen, bireysel farklılıkları dikkate alan, uygun öğrenme yaşantıları sağlayan ve öğrenenle birlikte 
öğrenen kişi şeklinde tanımlarken; Fer ve Cırık (2007) ise, öznel anlayış çerçevesinde yer alan yapılandırmacılığı içselleştirme ve öğrenme ortamlarını buna göre düzenleyebilme rollerini öne çıkarmaktadırlar. Buna göre, pozitivist anlayışı benimsemiş bir öğretmenin uygulamada yapılandırmacı roller sergilemesi beklenmemelidir. $\mathrm{Bu}$ düşüncelerden yola çıkarak, öğretmenin geleneksel eğitim anlayışında yer alan sadece bilgiyi aktaran, sınıf yöneten ve akademik başarıyı ürün olarak görüp bunu değerlendiren rollerden sıyrılarak, çok değişkenli rollere büründüğü yapılandırmacı eğitim anlayışını özümsemesi, içselleştirmesi çağdaşlığın, yeniliğin, pragmatist düşüncenin gerekliliği olarak görülmelidir. Öğretim sürecinin en temel öğesini oluşturan öğretmene biçilen rollerin ne kadar fazla olduğu düşünüldüğünde, yapılandırmacı ya da geleneksel öğretimi kendisine yakın bulan öğretmenlerin bu anlayışları ne şekilde algıladıkları da o derece önemli ve dikkate değerdir.

$\mathrm{Bu}$ algılardan yola çıkarak, öğretmen yetiştirme programı içerisinde yer alan öğretmen adaylarının edindikleri bilgiler, eğitim fakültesi çatısı altında ve buna bağlı olarak girdiği ortamlarda edindiği yaşantılar doğrultusunda öğrenme öğretme anlayışlarına yönelik algılarını metaforik anlamda nasıl tarif ettiklerini görmek, kendilerine biçilen rolleri de güncellemiş ve biçimlendirmiş olacaktır. Metafor kavramına bakıldığında ise, "bireylerin kendi dünyalarını anlamalarına ve yapılandırmalarına yönelik güçlü bir zihinsel haritalama ve modelleme mekanizması olarak tanımlayan Arslan ve Bayrakçı (2006) ile birlikte Morgan (1998), metafor kullanımını, genel olarak "dünyayı kavrayışımıza sinen bir düşünce biçimi ve bir görme biçimi" şeklinde tanımlamıştır. Bu yönüyle metafor, bir bireyin yüksek düzeyde soyut, karmaşık veya kuramsal bir olguyu anlamada ve açıklamada işe koşabileceği güçlü bir zihinsel araçtır.

Metafor yaratıcıdır; çünkü zihnimizi mevcut ve aşikar benzerliklerin, ilişkilerin ve görüşlerin ötesine, kendi yarattıkları yeni benzerliklere, ilişkilere ve görüşlere yönlendirir (Lakoff ve Johnson, 2005). Metaforlar, kelimeleri her zamanki bağlamlarından alıp farklı bir bağlama taşırlar. Ayrıca metaforlar bir dönemin, bir kültürün bir ortamın yansımasıdır ve onu kullananın faaliyetleri ve düşünceleri hakkında bilgi verir (Draaisma, 2000). Öğretmen yetiştirmede metaforlar, öğretim uygulamalarını yönlendirmede ve öğretmen adaylarının eğitim anlayışındaki yerini belirlemede bir araç olarak kullanılabilir (Vadeboncoeur ve Torres, 2003). Bu durumda, eğer bir eğitimci kendi öğretim amaçları, değerleri veya felsefesi ile uyumlu bir pedagojik değişiklik yapmak arzusunda ise bu eğitimcinin ilk önce bu boyutlara ilişkin şu anki durumunu gözden geçirmesi gerekir. Bunu gerçekleştirebilmesine yardımcı olacak en fazla potansiyele sahip olan zihinsel model ise 
metafordur. Çünkü ister farkında olalım ister olmayalım ister kabul edelim ister etmeyelim, bir zihinsel model olarak metaforlar her zaman bizimle birlikte yaşamaya devam etmektedirler (Saban; Koçbeker; Saban, 2006). Öğretmen adaylarının geçmişte sahip oldukları öğretmenlere ilişkin tutumlarının neler olduğunu ve onların ideallerindeki "öğretmen" hakkındaki düşüncelerinin daha çok hangi öğretmen rolleri üzerinde yoğunlaştığını metaforlar aracılığıyla analiz eden daha çok sayıda nitel ve nicel araştırmalara ihtiyacından (Saban, 2004) yola çıkılarak öğretmen adaylarının edindiği yaşantılar başta olmak üzere, öz yeterlikleri, dünyaya ve eğitime olan bakış açıları, bireysel farklılıkları dikkate alınarak öğrenme öğretme anlayışlarının ne yönde şekillendiği ölçülüp, yapılandırmacı eğitim anlayışını kendi bakış açılarına göre metaforlar üretmeleri ve böylece bu konudaki genel algılarının görülmeye çalışılması bu araştırmanın önemini oluşturmaktadir.

$\mathrm{Bu}$ araştırmayla farklı üniversitelerin eğitim fakültelerinde öğrenim gören öğretmen adaylarının öğrenme öğretme anlayış düzeyleri ve metaforik algılarının incelenmesi amaçlanmıştır. Bu amaç doğrultusunda aşağıdaki alt problemler belirlenmiştir:

1. Öğretmen adaylarının cinsiyet, sınıf ve branş değişkenlerine göre öğrenme öğretme anlayışları farklılaşmakta mıdır?

2. Eğitim fakültelerinde öğrenim gören öğretmen adaylarının yapılandırmacı eğitim anlayışını hangi metaforlarla açıklamaktadır?

3. Eğitim fakültelerinde öğrenim gören öğretmen adaylarının yapılandırmacı eğitim anlayışına yönelik metaforları, öğrenme öğretme anlayışlarına göre farklılaşmakta midir?

\section{Yöntem}

Bu bölümde araştırmanın modeline, katılımcı sayılarına, değişken özelliklerine, veri toplama araçlarına, güvenirlik geçerlik analizi sonuçlarına yer verilmiştir.

\section{Araștırma Modeli}

Çalışmada, nicel ve nitel veri toplama yöntemleri kullanarak bulgu ve sonuçların bir çerçeve içerisinde sunulmasına, analiz edilmesine ve bir araya getirilmesine imkân tanıyan karma yöntem kullanılmıştır. Karma yöntem araştırmalarında araştırmacılar; sıralı açıklayıcı tasarım, sıralı araştırıcı tasarım, sıralı dönüşümsel tasarım, eş zamanlı üçgenleme, eş zamanlı iç içe geçmiş tasarım ve eş zamanlı dönüşümsel tasarım olmak üzere altı çeşit tasarım 
kullanabilmektedir (Creswell, 2003). Bu araştırmada eş zamanlı üçgenleme modelinin kullanılması uygun görülmüştür. Eş zamanlı üçgenleme tasarımında nicel ve nitel veriler aynı zamanda toplanmakta ancak veriler ayrı ayrı analiz edilmektedir. Veriler yorumlanırken nitel ve nicel verilerin birbirine ne derece yakın olduğu saptanmaya çalışılmaktadır (Baki ve Gökçek, 2012).

\section{Katılımcılar}

Çalışma 2019-2020 eğitim öğretim yılında Türkiye'nin farklı bölgelerindeki üniversitelerinde öğrenim gören sınıf öğretmenliği, İngilizce, Türkçe, matematik, fen bilgisi, müzik öğretmenliğinden toplam 284 öğretmen adayıyla gerçekleştirilmiştir. Araştırmada basit seçkisiz örnekleme yoluna gidilmiştir. Basit seçkisiz örnekleme yöntemi ise, evrendeki her bir bireyin örnekleme seçilme şanslarının birbirine eşit ve eşit ve birbirinden bağımsız olması işlemidir (Gall., Gall, Borg, 1999).

Tablo 1. Örneklem Grubunun Değişkenlere Göre Dă̆ılımı

\begin{tabular}{|c|c|c|c|c|c|}
\hline Değişken & Grup & $\mathrm{F}$ & & & $\mathrm{f}$ \\
\hline \multirow[t]{2}{*}{ Cinsiyet } & $\mathrm{K}_{1 \mathrm{Z}}$ & 237 & & Eğitim bilimine giriş & 6 \\
\hline & Erkek & 47 & & Eğitim psikolojisi & 32 \\
\hline \multirow[t]{6}{*}{ Sınıf düzeyi } & 2.sinif & 101 & & $\begin{array}{l}\text { Öğretimi ilke } \quad \text { ve } \\
\text { yöntemleri }\end{array}$ & 74 \\
\hline & 3.sinif & 111 & \multirow{10}{*}{$\begin{array}{l}\text { Katkısı } \\
\text { en } \\
\text { yüksek } \\
\text { ders }\end{array}$} & Ölçme ve değerlendirme & 7 \\
\hline & 4.sinif & 72 & & $\begin{array}{l}\text { Öğretim tek. ve mat. } \\
\text { tasarımı }\end{array}$ & 14 \\
\hline & Sınıf öğretmenliği & 32 & & Özel Öğretim yöntemleri & 51 \\
\hline & $\begin{array}{ll}\text { Fen } & \text { bilgisi } \\
\text { öğretmenliği } & \end{array}$ & 44 & & Öğretmenlik uygulaması & 96 \\
\hline & $\begin{array}{l}\text { Matematik } \\
\text { öğretmenliği }\end{array}$ & 132 & & $\begin{array}{l}\text { Eğitimde } \quad \text { program } \\
\text { geliş̧tirme }\end{array}$ & 4 \\
\hline \multirow[t]{5}{*}{ Branş } & İngilizce öğretmenliği & 22 & & Hazır bulunuşluk düzeyi & 27 \\
\hline & $\begin{array}{l}\text { Sosyal bil. } \\
\text { Öğretmenliği }\end{array}$ & 13 & & Tahtada ders anlatmak & 11 \\
\hline & Türkçe öğretmenliği & 13 & & Materyal kullanmak & 50 \\
\hline & Müzik öğretmenliği & 28 & & Öğrencileri aktif kılmak & 187 \\
\hline & & & & Soru çözmek & 9 \\
\hline
\end{tabular}




\section{Veri Toplama Araci}

Araştırma kapsamında öğretmen adaylarının öğrenme öğretme anlayışlarının belirlenmek amaçlandığı bu çalışmada Teaching and Learning Conceptions Questionnaire (Öğretme ve Öğrenme Anlayışları Ölçeği) Chan ve Elliot (2004) tarafından geliştirilmiştir. Araştırma Hong Kong'da 385 gönüllü öğretmen adayı öğrenci üzerinde gerçekleştirilmiştir. Daha sonra Aypay (2011) tarafından Türkçe'ye uyarlama çalışması yapılan ölçeğin yapılandırmacı anlayış ve geleneksel anlayış olarak adlandırılan bu faktörlerden yapılandırmacı anlayış boyutu 12 maddeden, geleneksel anlayış boyutu 18 maddeden oluşmuştur. Otuz maddeden oluşan ölçek Doğrulayıcı Faktör Analizine tabi tutulmuş ve analiz sonuçları uyumlu bir modele $(\mathrm{GFI}=0.93, \mathrm{AGFI}=0.91, \mathrm{RMR} 0.50, \mathrm{RMSEA} 0.54)$ işaret etmiştir. İkinci bölümde ise "Öğretmen......... gibidir; çünkü............" şeklinde oluşturulan metafor formu kullanılmıştır.

Tablo 2. Öğrenme Öğretme Anlayışları Ölçeğinin Güvenirlik Katsayıları

$\begin{array}{cc}\text { Türkçe } & \text { Mevcut } \\ \text { Uyarlama } & \text { Örneklem } \\ \text { Çalışması } & \end{array}$

(Aypay,2011)

$(\mathrm{N}=209)$

Yapılandırmacı Anlayış Alt Boyutu

12 madde

.86

.94

Geleneksel Anlayış Alt Boyutu

18 madde

.84

.90

Toplam

30 madde

.84

Kullanılacak ölçeklerde; ön deneme çalışmaları için .60, temel çalışmalar için .80 ve uygulamalı çalışmalar için .90- .95 güvenirlilik oranlarının gerekli olduğu belirtilmiş; sosyal bilimlerde yapılan araştırmanın türüne göre güvenirlilik katsayıları değişmekle birlikte, bilimsel içerikli çalışmalarda .70 ve yetenek, ilgi ve beceri gerektiren çalışmalarda kullanılacak ölçekler için ise .85 düzeyinde bir güvenirlik katsayısı istenmektedir (Şencan, 2005). Yapılan çalışmada ölçeğin tüm maddelerine yer verilerek yapılan Türkçe'ye uyarlama çalışmasının güvenirlik analizi sonucuna göre Cronbach alpha değeri .84; mevcut uygulamanın güvenirlik analizi sonucuna göre Cronbach alpha değeri .89 olarak ölçülmüştür. $\mathrm{Bu}$ durumda ölçeğin güvenilir bir araç olduğu söylenebilir. Bunun yanında ölçeğin alt boyutlarına göre güvenirlik katsayılarına bakıldığında örneklem grubundan genel anlamda yeterli güvenirlik katsayılarının elde edildiği yorumu yapılabilir. 


\section{Verilerin Toplanması ve Analizi}

Araştırmaya katılan öğretmen adaylarına “Öğrenme ve Öğretme Anlayışı Ölçeği” ve metafor sorusu birlikte verilmiştir. Öğretmen adaylarından veriler Google Form üzerinden online olarak toplanmıştır. Ulaşılan nicel verilerin analizinde öncelikle betimsel istatistiklerden ortalama ve standart sapma hesaplamaları yapılmış; sonrasında da bağımsız değişkenlere normallik testi olarak Kolmogorov-Smirnov testi uygulanmıştır. Elde edilen sonuçlar non parametrik dağılım gösterdikleri görülerek, Mann Whitney U, Kruskall Wallis $\mathrm{H}$, Dunnet $\mathrm{C}$ testleri uygulanarak öğretmen adaylarının öğrenme öğretme anlayışları üzerinde anlamlı farklar oluşturup oluşturmadığına bakılmıştır.

Nitel verilerin çözümlenmesinde ise içerik analizi yöntemi kullanılmıştır. İçerik analizinin en önemli amacı benzerlik gösteren verileri kavramlar ve temalar çatısı altında bir araya getirmek ve ulaşılan sonuçları okuyucunun anlayabileceği bir şekilde düzenleyerek yorumlamaktır (Yıldırım ve Şimşek, 2008). Ayrıca metaforların çözümlenmesinde Saban'ın (2008) metafor çözümleme aşamaları kullanılmıştır.

Kodlama ve Eleme: Bu aşamada öğretmen adaylarının EPG dersini açıklamada kullandıkları metaforlar incelenmiştir. Metaforun EPG dersi ile açık bir şekilde ilişkilendirip ilişkilendiremediği incelenmiş, metafor özelliği gösterdiğine inanılan ifadeler listelenmiştir. Toplanan tüm verilerde metafor üretildiği görülmüştür. Benzer metaforların da öğretmen adayları tarafından üretildiği görülmektedir.

Derleme ve Kategori Geliştirme: Oluşturulan 209 metafor ve açıklama incelenmiş öğretmen adaylarının “öğretmen” kavramını nasıl algıladıkları anlaşılmaya çalışılmıştır. Metaforlar, "metaforun konusu ile kaynağı arasındaki ilişki" açısından analiz edilmiştir. Yapılan içerik analizi sonucunda benzer metaforlarla ilişkilendirilen toplam ...... kategori oluşturulmuştur.

Güvenirlik ve Geçerlik: Üretilen tüm metaforlar liste halinde sunulmuştur. Metaforlar ve bunlara ilişkin yapılan açıklamalardan hareketle ulaşılan kategoriler hakkında uzman görüşüne başvurulmuştur. Güvenirlik konusunda Tanberkan (2015), içerik analizinin güvenirliğinin dayandığı noktanın kodlama olduğunu ve kodlamalar ile açık, anlaşılır kategoriler oluşturulmasının güvenirliğin göstergelerinden biri olduğunu ifade etmektedir. Öğülmüş (1991) de, içerik analizinin güvenilir olabilmesi için, nesnel olması gerektiğini, farklı gözlemcilerin aynı materyal üzerinde aynı olguları gözlemleyebilmeleri için daha önceden kategorilerin belirlenmesinin ve açıkça tanımlanmasının önemli olduğunu 
belirtmektedir. Buradan yola çıkarak araştırmacıların birbirlerinden bağımsız olarak elde edilen metaforları kodlamış ve kategorilere ayırmışlardır. Analizler tamamlandığında yüksek oranda benzer kodlamalara ve kategori isimlerine ulaşıldığı görülmüş̧ür. Araştırmanın geçerli olabilmesi güvenilir olmasıyla ilişkili olsa da, güvenirlik geçerlik için tek başına yeterli bir ölçüt değildir. Yıldırım ve Şimşek (2008), geçerliğin sağlanması için araştırmacının araştırdığı olguyu, olabildiğince yansız gözlemesi gerektiğini belirtip toplanan verilerin ayrıntılı olarak rapor edilmesinin ve sonuçlara nasıl ulaşıldığının açıklanmasının geçerliğin önemli ölçütleri arasında yer aldığını ifade etmektedir. Bu araştırmada da verilere nasıl ulaşıldığı, kategorilerin nasıl oluşturulduğu ve bulunan sonuçlar ayrıntılı olarak açıklandığı için araştırmanın geçerli olduğu düşünülmektedir.

\section{Bulgular}

Bu bölümde araştırma kapsamında belirlenen alt problemlere yanıt bulmak amacıyla yapılan analizlere ve bu analizlerden elde edilen verilere yer verilmiştir.

Eğitim Fakültelerinde Öğrenim Gören Öğretmen Adaylarının Belirlenen Değişkenlere Göre Öğrenme Öğretme Anlayışlarını Algılama Düzeyleri

Araştırmanın birinci alt probleminde belirlenen bağımsız değişkenlerin öğretmen adaylarının öğrenme öğretme anlayışları üzerinde anlamlı bir fark oluşturup oluşturmadıkları görülmeye çalışılmıştır.

Tablo 3. Belirlenen Değişkenlere Uygulanan K-S Testi

$$
\text { Normallik Testi }
$$

Kolmogorov-Smirnov

Serbestlik

İstatistik Derecesi Anlaml1lık Düzeyi

\begin{tabular}{lccc}
\hline Cinsiyet & .50 & 284 & .00 \\
Sinıf Düzeyi & .23 & 284 & .00 \\
Branş & .32 & 284 & .00 \\
Katkısı En Yüksek Ders & .23 & 284 & .00 \\
Öğretme Faaliyeti & .38 & 284 & .00
\end{tabular}


N.C. Dedebali ve S. Süral / Pamukkale Üniversitesi Eğitim Fakültesi Dergisi, 54, 158-187, $2022 \quad 167$

Kolmogorov-Smirnov (K - S) testi ile bir örneklemden elde edilen verilerin normal dağglım gösterip göstermediği incelenir. Normal değer gösteriyorsa parametrik, göstermiyorsa nonparametrik testler kullanılır. "p" değerinin 0.05 düzeyinde anlamlı çıkması $(\mathrm{p}<0.05)$ nonparametrik; $p>0.05$ durumunda ise parametrik testlerin kullanılması gerekir (Can, 2014, s.89). Böylece Kolmogorov-Smirnov testi uygulanmış ve tüm değişkenlerde .05 düzeyinde anlamlı bir fark gösterdiği için nonparametrik testler kullanılmıştır.

\section{Eğitim Fakültelerinde Öğrenim Gören Öğretmen Adaylarının Belirlenen Değişskenlere} Göre Öğrenme Öğretme Anlayışlarının Anlamlılık Düzeyleri (Yapılandırmacı Anlayış)

Araştırmada belirlenen birinci alt problemde, belirlenen değişkenlerin öğretmen adaylarının öğrenme öğretme anlayışları üzerinde anlamlı bir fark oluşturup oluşturmadığına bakmak amaçlanmaktadır. Çalışmada kullanılan ölçek daha önce de ifade edildiği gibi iki alt boyuttan oluşmaktadır. Bundan dolayı değişkenlerin öğrenme öğretme anlayışları üzerinde nasıl bir fark oluşturduğunu görmek için önce yapılandırmacı anlayış alt boyutu incelenmiştir.

Tablo 4. Belirlenen Değişkenlerin Yapılandırmacı Anlayış Farklılaşma Düzeyleri

\begin{tabular}{|c|c|c|c|c|c|c|c|}
\hline $\begin{array}{c}\text { Alt } \\
\text { Boyut }\end{array}$ & Gruplar & $\mathrm{N}$ & Sira Ort. & Sira Top. & $\mathrm{U}$ & $\mathrm{Z}$ & $\mathrm{P}$ \\
\hline \multirow{2}{*}{ Cinsiyet } & Kadın & 237 & 148.4 & 35193.0 & \multirow{2}{*}{4149.0} & \multirow{2}{*}{-2.771} & \multirow{2}{*}{$.006^{*}$} \\
\hline & Erkek & 47 & 112.2 & 5277.0 & & & \\
\hline $\begin{array}{c}\text { Alt } \\
\text { Boyutlar }\end{array}$ & Gruplar & $\mathrm{N}$ & Sira Ort. & $\chi^{2}$ & $\mathrm{df}$ & $\mathrm{p}$ & Fark \\
\hline \multirow{3}{*}{$\begin{array}{c}\text { Sinıf } \\
\text { Düzeyi }\end{array}$} & (1) 2.Sinif & 101 & 127.2 & \multirow{3}{*}{9.852} & \multirow{3}{*}{2} & \multirow{3}{*}{$.007^{*}$} & \multirow{3}{*}{$1-3$} \\
\hline & (2) 3.Sinıf & 111 & 140.7 & & & & \\
\hline & (3) 4.Sinif & 72 & 166.6 & & & & \\
\hline \multirow{5}{*}{ Branş } & (1) Sınıf Öğretmenliği & 32 & 160.6 & \multirow{5}{*}{14.636} & \multirow{5}{*}{6} & \multirow{5}{*}{$.023^{*}$} & \multirow{5}{*}{$\begin{array}{l}2-5 \\
3-5 \\
5-7\end{array}$} \\
\hline & $\begin{array}{l}\text { (2) Fen Bilgisi } \\
\text { Öğretmenliği }\end{array}$ & 44 & 149.9 & & & & \\
\hline & $\begin{array}{l}\text { (3) Matematik } \\
\text { Öğretmenliğ }\end{array}$ & 132 & 125.7 & & & & \\
\hline & $\begin{array}{l}\text { (4) İngilizce } \\
\text { Öğretmenliği }\end{array}$ & 22 & 155.5 & & & & \\
\hline & $\begin{array}{l}\text { (5) Sosyal Bil. } \\
\text { Öğretmenliği }\end{array}$ & 13 & 239.0 & & & & \\
\hline
\end{tabular}


(6) Türkçe

Öğretmenliği

$13 \quad 154.2$

(7) Müzik Öğretmenliği $28 \quad 112.8$

\begin{tabular}{|c|c|c|c|c|c|c|c|}
\hline \multirow{8}{*}{$\begin{array}{l}\text { Katkısı } \\
\text { En } \\
\text { Yüksek } \\
\text { Ders }\end{array}$} & Eğitim Bilimine Giriş & 6 & 126.9 & \multirow{8}{*}{5.573} & \multirow{8}{*}{7} & \multirow{8}{*}{.590} & \\
\hline & Eğitim Psikolojisi & 32 & 127.3 & & & & \\
\hline & $\begin{array}{l}\text { Öğretim İlke ve } \\
\text { Yöntemleri }\end{array}$ & 74 & 133.8 & & & & \\
\hline & $\begin{array}{l}\text { Ölçme ve } \\
\text { Değerlendirme }\end{array}$ & 7 & 141.0 & & & & \\
\hline & $\begin{array}{l}\text { Öğretim Tek. Ve Mat. } \\
\text { Tas. }\end{array}$ & 14 & 128.8 & & & & \\
\hline & $\begin{array}{l}\text { Özel Öğretim } \\
\text { Yöntemleri }\end{array}$ & 51 & 160.8 & & & & \\
\hline & $\begin{array}{l}\text { Öğretmenlik } \\
\text { Uygulaması }\end{array}$ & 96 & 146.7 & & & & \\
\hline & $\begin{array}{l}\text { Eğitimde Program } \\
\text { Gelişt. }\end{array}$ & 4 & 161.1 & & & & \\
\hline \multirow{5}{*}{$\begin{array}{l}\text { Öğretme } \\
\text { Faaliyeti }\end{array}$} & $\begin{array}{l}\text { (1) Hazır bulunuşluk } \\
\text { düzeyi }\end{array}$ & 27 & 119.4 & \multirow{5}{*}{10.294} & \multirow{5}{*}{4} & \multirow{5}{*}{$.036^{*}$} & \multirow{5}{*}{$\begin{array}{l}1-3 \\
3-5\end{array}$} \\
\hline & $\begin{array}{l}\text { (2) Tahtada ders } \\
\text { anlatmak }\end{array}$ & 11 & 116.0 & & & & \\
\hline & (3) Materyal kullanmak & 50 & 163.3 & & & & \\
\hline & $\begin{array}{l}\text { (4) Öğrencileri aktif } \\
\text { kılmak }\end{array}$ & 187 & 144.3 & & & & \\
\hline & (5) Soru Çözmek & 9 & 90.3 & & & & \\
\hline
\end{tabular}

$* p<0.05$ düzeyinde anlaml 1

Tablo 4'e bakıldığında araştırmada fark oluşturup oluşturmadığı görülmek istenen bağımsız değişkenlerden cinsiyet, sınıf düzeyi, branş ve öğretme faaliyeti değişkenlerinin öğretmen adaylarının yapılandırmacı öğrenme öğretme anlayışları üzerinde anlamlı bir fark oluştururken; "katkısı en yüksek ders" değişkeninin bir fark oluşturmadığı görülmektedir.

İlk olarak cinsiyet değişkeni incelendiğinde kız öğretmen adaylarının sıra ortalamalarının 148.4 (U:4149.0; Z: -2.771) erkek öğretmen adaylarından 112.2 (U:4149.0; Z: -2.771) daha yüksek olduğu sonucu görülmektedir. Buna göre kız öğretmen adaylarının öğretme 
N.C. Dedebali ve S. Süral / Pamukkale Üniversitesi Eğitim Fakültesi Dergisi, 54, 158-187, 2022

anlayışlarının erkek öğretmen adaylarına göre daha yapılandırmacı bir anlayışa yatkın olduğu şeklinde yorumlanabilir.

Sınıf düzeyi ortalamalarında anlamlı farkın görüldüğü; ancak değişken içerisinde 2'den fazla alt grup yer aldığı için yapılan Kruskall Wallis analizinden sonra Dunnet T3 post hoc testi kullanılarak hangi gruplar arasında anlamlı farkın olduğu görülmeye çalışılmıştır. Buna göre 2. sınıflar ile 4. sinıflar arasında anlamlı farkın olduğu, bu farkın ise 4. sınıflar lehine çıktığı söylenebilir.

Araştırmada yer alan bir diğer değişken olan branş ortalamalarının öğretmen adaylarının yapılandırmacı öğretme anlayışları üzerindeki anlamlılık düzeylerine bakıldığında 0.05 düzeyinde anlamlı bir farkın olduğu görülmektedir. Benzer şekilde Dunnet T3 post hoc testi uygulandığında anlamlı farkların üç farklı alt gruplar arasında çıkmaktadır. Bunlar; fen bilgisi ile sosyal bilgiler öğretmenliği, matematik ile sosyal bilgiler öğretmenliği ve müzik ile sosyal bilgiler öğretmenliği alt gruplarıdır. Üçünde de benzer görülen ve dikkat çekici olan durum tüm karşılaştırmalarda anlamlı farkın sosyal bilgiler öğretmenliğinde öğrenim gören öğretmen adaylarının lehine olmasıdır.

Araştırmada yer alan son bağımsız değişken "öğretme faaliyeti” nde ise anlamlı farkların "hazır bulunuşluk düzeyleri ile materyal kullanmak" ve "materyal kullanmak ile soru çözmek" alt grupları arasında olduğu Tablo 4'te verilen değerlere göre ifade edilebilir. Yapılan karşılaştırmalarda anlamlı farkların çıktığı her iki alt grup arasında da "materyal kullanmak" öğretme faaliyetinin lehine bir sonucun çıktığı grupların sıra ortalamalarına bakılarak söylenebilir.

\section{Eğitim Fakültelerinde Öğrenim Gören Öğretmen Adaylarının Belirlenen Değişkenlere Göre Öğrenme Öğretme Anlayışlarının Anlamlılık Düzeyleri (Geleneksel Anlayış)}

Araştırma kapsamında ulaşılmak istenen amaçlara yönelik kullanılan öğrenme öğretme anlayışları ölçeğinin diğer bir alt boyutu olan geleneksel öğretme anlayışının belirlenen değişkenlere göre anlamlı farklar oluşturup oluşturmadığına Tablo 5 'teki değerlere bakılarak analiz edilmeye çalışılmıştır.

Tablo 5'e bakıldığında araştırmada fark oluşturup oluşturmadığı görülmek istenen bağımsız değişkenlerden cinsiyet, sınıf düzeyi, branş ve öğretme faaliyeti değişkenlerinin öğretmen adaylarının geleneksel öğrenme öğretme anlayışları üzerinde anlamlı bir fark oluştururken; "katkısı en yüksek ders” değişkeninin bir fark oluşturmadığı görülmektedir. 
Tablo 5. Belirlenen değişkenlerin geleneksel anlayış üzerindeki farklılaşma düzeyleri

\begin{tabular}{|c|c|c|c|c|c|c|c|}
\hline $\begin{array}{c}\text { Alt } \\
\text { Boyut }\end{array}$ & Gruplar & $\mathrm{N}$ & Sira Ort. & Sira Top. & $\mathrm{U}$ & $\mathrm{Z}$ & $\mathrm{P}$ \\
\hline \multirow{2}{*}{ Cinsiyet } & K1z & 237 & 134.5 & 31898.0 & \multirow{2}{*}{3695.0} & \multirow{2}{*}{-3.646} & \multirow{2}{*}{.000} \\
\hline & Erkek & 47 & 182.3 & 8572.0 & & & \\
\hline $\begin{array}{c}\text { Alt } \\
\text { Boyutlar }\end{array}$ & Gruplar & $\mathrm{N}$ & Sira Ort. & $\chi^{2}$ & df & $\mathrm{p}$ & Fark \\
\hline \multirow{3}{*}{$\begin{array}{l}\text { Sinıf } \\
\text { Düzeyi }\end{array}$} & (1) 2. Sinif & 101 & 143.1 & \multirow{3}{*}{6.247} & \multirow{3}{*}{2} & \multirow{3}{*}{$.044^{*}$} & \multirow{3}{*}{$2-3$} \\
\hline & (2) 3.Sinif & 111 & 154.3 & & & & \\
\hline & (3) 4.Sinıf & 72 & 123.3 & & & & \\
\hline \multirow{7}{*}{ Branş } & (1) Sınıf Öğretmenliği & 32 & 98.1 & & & & \multirow{7}{*}{$\begin{array}{l}1-2 \\
1-7 \\
3-7\end{array}$} \\
\hline & $\begin{array}{lcl}(2) & \text { Fen } & \text { Bilgisi } \\
\text { Öğretmenliği } & \end{array}$ & 44 & 165.4 & & & & \\
\hline & (3) Matematik & 132 & 131.3 & & & & \\
\hline & $\begin{array}{ll}(4) & \text { İngilizce } \\
\text { Öğretmenliği } & \end{array}$ & 22 & 114.5 & 29.889 & 6 & $.006^{*}$ & \\
\hline & $\begin{array}{l}(5) \quad \text { Sosyal } \\
\text { Öğretmenliği }\end{array}$ & 13 & 104.0 & & & & \\
\hline & $\begin{array}{ll}\text { (6) } & \text { Türkçe } \\
\text { Öğretmenliği } & \end{array}$ & 13 & 120.8 & & & & \\
\hline & (7) Müzik Öğretmenliği & 28 & 190.9 & & & & \\
\hline \multirow{7}{*}{$\begin{array}{l}\text { Katkısı } \\
\text { En } \\
\text { Yüksek } \\
\text { Ders }\end{array}$} & Eğitim Bilimine Giriş & 6 & 148.8 & \multirow{7}{*}{12.856} & \multirow{7}{*}{7} & \multirow{7}{*}{.076} & \\
\hline & Eğitim Psikolojisi & 32 & 116.4 & & & & \\
\hline & $\begin{array}{l}\text { Öğretim İlke ve } \\
\text { Yöntemleri }\end{array}$ & 74 & 131.7 & & & & \\
\hline & $\begin{array}{ll}\text { Ölçme } & \text { ve } \\
\text { Değerlendirme } & \end{array}$ & 7 & 184.6 & & & & \\
\hline & $\begin{array}{l}\text { Öğretim Tek. Ve Mat. } \\
\text { Tas. }\end{array}$ & 14 & 120.7 & & & & \\
\hline & $\begin{array}{l}\text { Özel Öğretim } \\
\text { Yöntemleri }\end{array}$ & 51 & 142.7 & & & & \\
\hline & $\begin{array}{l}\text { Öğretmenlik } \\
\text { Uygulaması }\end{array}$ & 96 & 160.7 & & & & \\
\hline
\end{tabular}


Eğitimde Program

Gelişt.
4

106.2

$\begin{aligned} & \text { (1) Hazır bulunuşluk } 27 \\ & \text { düzeyi }\end{aligned}$
(38.9

(2) Tahtada ders 11 anlatmak

Öğretme

Faaliyeti

(3) Materyal kullanmak 50

143.7

14.072

4

$1-2$

(4) Öğrencileri aktif 187

k1lmak

136.1

(5) Soru Çözmek

$\begin{array}{ll}9 & 177.9\end{array}$

$* \mathrm{p}<0.05$ düzeyinde anlamlı

İlk olarak cinsiyet değişkeni incelendiğinde erkek öğretmen adaylarının sıra ortalamalarının 182.3 (U: 3695.0; Z: -3.646) erkek öğretmen adaylarından 134.5 (U: 3695.0; Z: -3.646) daha yüksek olduğu sonucu görülmektedir. Buna göre erkek öğretmen adaylarının öğretme anlayışlarının kız öğretmen adaylarına göre daha geleneksel bir anlayışa yatkın olduğu şeklinde yorumlanabilir.

Sınıf düzeyi değişkeninde de anlamlı farkın görüldüğü; ancak değişken içerisinde 2'den fazla alt grup yer aldığg için yapılan Kruskall Wallis analizinden sonra post hoc testi kullanılarak hangi gruplar arasında anlamlı farkın olduğu görülmeye çalışılmıştır. Buna göre 3. sınıflar ile 4. sınıflar arasında anlamlı farkın olduğu, bu farkın ise 3. sınıflar lehine çıktığı söylenebilir.

Araştırmada yer alan bir diğer değişken olan branş değişkeninin öğretmen adaylarının yapılandırmacı öğretme anlayışları üzerindeki anlamlılık düzeylerine bakıldığında 0.05 düzeyinde anlamlı bir farkın olduğu görülmektedir. Benzer şekilde Dunnet C post hoc testi uygulandığında anlamlı farkların üç farklı alt gruplar arasında çıkmaktadır. Bunlar; fen bilgisi ile sınıf öğretmenliği arasında fen bilgisi öğretmeni adaylarının lehine, sınıf ile müzik öğretmenliği arasında müzik öğretmeni adaylarının lehine ve müzik ile matematik öğretmenliği arasında ad yine müzik öğretmeni adaylarının lehine anlamlı farkların çıktığg alt gruplarıdır.

Araştırmada yer alan son bağımsız değişken olan "öğretme faaliyeti” değişkeni üzerinde yapılan Kruskall Wallis testi sonuçlarına göre anlamlı farklar görüldüğü Tablo 5 'te gösterilmiştir. Anlamlı farkın hangi gruplar arasında olduğu Dunnet C post hoc testiyle belirlenmeye çalışılmıştır. Buna göre "tahtada ders anlatmak" alt grubunun "hazır 
bulunuşluk düzeyini belirlemek", "materyal kullanmak" ve "öğrencileri aktif kılmak" grupları üzerinde daha yüksek sıra ortalamalarına sahip olduğu sonucuna ulaşılmıştır.

\section{Öğretmen Adaylarının Öğrenme Öğretme Anlayışlarına Yönelik Metaforik Algılarının İncelenmesi}

Araştırmada belirlenen ikinci alt problem ise "Eğitim fakültelerinde öğrenim gören öğretmen adaylarının yapılandırmacı eğitim anlayışını hangi metaforlarla açıklamaktadır?” şeklinde belirlenmiştir. Buna göre öğretmen adaylarına verilen “Öğretmen.........gibidir. Çünkü........" şeklinde yarım bırakılmış cümleyi kendi algılamalarına göre doldurmaları istenmiştir. Veriler elde edildikten sonra her iki araştırmacı tarafından ayrı ayrı kategorilere ayrılarak her kategorinin frekans değerleri belirlenerek tablolaştırılmış ve daha sonrasında da kategorilere ilişkin örnek cümlelere yer verilmiştir.

Tablo 6. Öğretmen adaylarının öğrenme ögrretme anlayışlarına yükledikleri metaforlar

\begin{tabular}{llllll}
\hline No & Metafor - Frekans & No & Metafor - Frekans & No & Metafor - Frekans \\
\hline 1 & Işık - (f: 19) & 28 & Örnek (f: 2) & 55 & Hayat Değiştirici \\
2 & Rehber - (f: 17) & 29 & Google (f: 2) & 56 & Materyal \\
3 & Pusula - (f: 16) & 30 & Rota (f: 6) & 57 & Yapboz \\
4 & Güneş - (f: 16) & 31 & Kar kürüme aracı (f:2) & 58 & Tetikçi \\
5 & Mum - (f: 13) & 32 & Lider (f: 5) & 59 & Inşaat Ustası \\
6 & Su - (f: 13) & 33 & Bilge (f: 4) & 60 & Kuyu \\
7 & Kitap - (f: 17) & 34 & Çiğköfte (f: 2) & 61 & Merdiven \\
8 & Yol Gösterici - (f: 9) & 35 & Kilavuz (f: 2) & 62 & Uzay \\
9 & Anne - (f: 9) & 36 & Teknoloji (f: 2) & 63 & Kalp \\
10 & Aile - (f: 8) & 37 & Okyanus (f: 2) & 64 & Öğrenci \\
11 & Bahçıvan - (f: 7) & 38 & Dağ & 65 & Harita \\
12 & Kuzey Yıldız1 - (f: 6) & 39 & Tuz & 66 & Cüzdan \\
13 & Fener - (f: 6) & 40 & Ev & 67 & Yağmur \\
14 & Ayna - (f: 6) & 41 & & Aydın kişi & malzemesi \\
\hline & & & & 68 & \\
\hline
\end{tabular}




$\begin{aligned} 15 & \text { Ağaç - (f: 5) } & 42 & \text { Yenilikçi } & 69 & \text { Meyve Ağacı } \\ 16 & \text { Trafik Levhası - (f: 4) } & 43 & \text { Karaciğer } & 70 & \text { Nöron } \\ 17 & \text { Yol - (f: 4) } & 44 & \text { Araç } & 71 & \text { Gökkuşağı } \\ 18 & \text { Çiçek - (f: 3) } & 45 & \text { Açık büfe } & 72 & \text { Miknatıs } \\ 19 & \text { Rol Modeli - (3) } & 46 & \text { Mizrap } & 73 & \text { Aşçı } \\ 20 & \text { Meşale - (f: 3) } & 47 & \text { Korona virus } & 74 & \text { Nehir yatağ1 } \\ 21 & \text { Altın - (f: 4) } & 48 & \text { Kullanım Kılavuzu } & 75 & \text { Fabrika } \\ 22 & \text { Bilgi Kaynağ1 - (f: 3) } & 49 & \text { Ilaç - (f: 3) } & 76 & \text { Orman } \\ 23 & \text { Arkadaş - (f: 8) } & 50 & \text { Hazine } & 77 & \text { Bina } \\ 24 & \text { Deniz - (f: 3) } & 51 & \text { Toprak } & 78 & \text { Kahraman } \\ 25 & \text { Mühendis - (f: 5) } & 52 & \text { Cevap Anahtarı } & 79 & \text { Bilgi aktaran } \\ 26 & \text { Kaşif (f: 2) } & 53 & \text { Kaptan } & & \\ 27 & \text { Dost (f: 2) } & 54 & & & \end{aligned}$

Tablo 6'ya bakıldığında öğretmen adaylarının öğrenme öğretme anlayışına yönelik olarak öğretmene yükledikleri en fazla metaforun "1şı1k (f:19)" olduğu sonrasında da "rehber (f:17)”, “kitap (f17)”, “pusula (f:16)”, “güneş (f:16)”, “mum (f:13)”, “su (f13)”, şeklinde ilerlediği görülmektedir. Genel olarak bakıldığında öğretmen adaylarının yükledikleri metaforlarda soyut kavramlar olduğu gibi somut olgulara da yer verdikleri söylenebilir. Genel olarak ifade edilecek olursa 79 farklı metafor ile öğretmen adaylarının öğretmenlere çok farklı bakış açılarıyla metaforlar yükledikleri görülmektedir.

Öğretmen adaylarından elde edilen veriler ışığında ortaya çıkan metaforlar analiz edildiğinde hayatı kolaylaştırıcı, mesleki ve insani roller, doğanın sundukları, faydalı eşya, organizmada bulunanlar gibi kategoriler elde edilmiştir.

"Hayatı kolaylaştırıcı" kategorisinde yer alan metaforlarda daha çok yol gösterici, rehber, öğrenciye hayatı kolaylaştırıcı yönde yaklaşıldığı görülmektedir. Örnek verilecek olursa bir öğretmen adayının (Ö6) "Yol gibidir çünkü kendimiz keşfede keşfede buluruz." Şeklinde ifade ederken bir başka öğretmen adayı (Ö41) "Deniz feneri gibidir geleceğe 1şık tutar." şeklinde görüş bildirmiştir. 


\begin{tabular}{llc}
\hline \multicolumn{1}{c}{ Kategoriler } & Frekans Değerleri \\
\hline$\square$ & Hayatı kolaylaştırıcı & 149 \\
\hline & Mesleki ve insani roller & 32 \\
\hline & Doğanın sundukları & 54 \\
\hline & Faydalı eşya & 45 \\
\hline & Organizmada bulunanlar & 4 \\
\hline
\end{tabular}

“Mesleki ve insani roller" olarak adlandırılan bu kategoride ise öğretmen adaylarının görüşlerinde daha çok öğretmenin farklı mesleklerin özelliklerini kendisinde barındırdığını ve farklı karakteristik özelliklere sahip olan biri olarak öğretmeni nitelendirdiği söylenebilir. Buna göre bir öğretmen adayı (Ö54) "Kaptan, ögrencileri hedefe ulaştırmada ve o süreçte doğru yolları bulmada yardımcı olduğu için.” derken; bir başka öğretmen adayı (Ö135) "Bahçıvan gibidir çünkü ögrencilerin her biri bir çicekse onların ihtiyaçlarını bilir onların yetişmesi için uygun bir ortam hazırlar.” şeklinde öğretmene metafor yüklemiştir.

"Doğanın sundukları" adıyla etiketlenen bu kategoride ise öğretmen adaylarının öğretmene, doğanın yetiştirdiği ve varlığı ile insanoğluna hayat veren olgu ve olayları düşünerek anlam yüklediği düşünülebilir. Bu düşünceyi destekleyen öğretmen adayı (Ö128) “Öğretmen ă̆aç gibidir, çünkü yetiştireceği her öğrenci gelecek için verimli birer meyve olacaktır." şseklinde ifade ederken; başka bir öğretmen adayı ise (Ö165) "Uzay gibidir. Iç̧inde her türden ve çeşitten varlı̆̆ barındırır." diyerek belirlenen kategoriyi desteklemektedir.

"Faydalı eşya" adı verilen bu kategoride ise öğretmen adaylarının pragmatist bir bakış açısıyla öğretmene farklı metaforlar yükledikleri görülmüştür. Böylece faydalı eşyaların hayatın içerisinde insanoğluna ne kadar yararlı oluyorsa; öğretmenin de öğrencilerine o kadar faydalı olduğu anlamı elde edilen veriler ışığında çıkarılabilir. Bu bağlamda bir öğretmen adayının (Ö205) "öğretmen bina öğrenciler binada yaşayanlar gibidir binanın temeli sağlam olmazsa en ufak sallantıda yıkılır." ifadesini kullanırken; bir 
N.C. Dedebali ve S. Süral / Pamukkale Üniversitesi Eğitim Fakültesi Dergisi, 54, 158-187, 2022175 başka öğretmen adayı da (Ö227) “Öğretmen kar küreme aracı gibidir çağdaşlı̆̆a giden yolu açar." diyerek belirlenen kategoriyi açıkladığı görülmektedir.

Son belirlenen kategori ise "Organizmada bulunanlar" adı altında sınıflanan metaforlar sonucunda oluşmuş ve öğretmen adaylarının, insan bedeni içinde kendine yer bulan her şeyin üstlendiği eylemlerin benzerini öğretmenin gerçekleştirdiği düşüncesinden yola çıkarak bu anlamları yükledikleri düşünülebilir. Bu açıdan bakıldığında bir öğretmen adayının (Ö239) “Kalp gibidir çünkü tüm sınıfı yönetir.” İfadesini, bir başka öğretmen adayının ise (Ö14) “Korona virüs gibidir; çünkü bulaşıcıdır insanda bıraktığı etki gibi. Ve ögrenmek istemeyen yani bă̆lşıklı̆̆ düşük olanda ya da bilgili olmaya bahaneler üreten yani kronik hastalara iç dünyasına döndürerek gerçekleri farkına vardırır." ifadesini kullanması araştırmacıların düşüncesini destekler niteliktedir.

\section{Öğrenme Öğretme Anlayışlarına Yönelik Düzeylerle Belirlenen Metaforların Karşılaştırılması}

Araştırmanın üçüncü ve son alt probleminde ise "Eğitim fakültelerinde öğrenim gören öğretmen adaylarının yapılandırmacı eğitim anlayışına yönelik metaforları, öğrenme öğretme anlayışlarına göre farklılaşmakta mıdır?” sorusu belirlenmiş ve öğretmen adaylarının öğrenme öğretme anlayışlarına yönelik belirlenen puanları en yüksekten en düşüğe doğru sıralanmıştır. Daha sonrasında ise en yüksek puana sahip üst \%27'lik dilime giren, en düşük puana sahip alt \%27'lik dilime giren öğretmen adaylarının metaforları karşılaştırılmıştır. Araştırma örnekleminde toplam 284 öğretmen adayı yer aldığ düşünüldüğünde \%27’lik Üst ve Alt gruplarda karşılaştırmaya dahil olan kişi sayısı 77 olarak belirlenmiştir.

Tablo 8'e bakıldığında \%27'lik üst grup içerisinde en fazla yer alan kategorinin hayat kolaylaştırıcı (f:41) olduğu görülürken organizmada bulunanlar kategorisinde hiçbir metaforun yer almadığı söylenebilir. En düşük öğrenme öğretme anlayışı puanlarına sahip olan 77 öğretmen adayının yükledikleri metaforların frekans dağılımına bakıldığında ise faydalı eşya (f:33) kategorisinde bir yığılmanın olduğu, mesleki ve insan rolleri kategorisi (f:17) ile doğanın sundukları (f:19) kategorisinin birbirine yakın olduğu sonucuna ulaşılmaktadır. Üst gruptaki dağılımda frekans değeri olmayan "organizmada bulunanlar" kategorisine ait bir metaforun yer alması da Tablo 8'de gösterilmektedir. 
Tablo 8. Öğretmen adaylarının ögretmenlere yükledikleri metaforların öğrenme ögretme anlayışlarına göre frekans dă̆ılımı

\begin{tabular}{|c|c|c|c|c|}
\hline & \multicolumn{4}{|c|}{ Öğrenme Öğretmen Anlayış Düzeyleri } \\
\hline & \multicolumn{2}{|c|}{ \%27’lik Üst Grup } & \multicolumn{2}{|c|}{$\% 27$ 'lik Alt Grup } \\
\hline & $\mathrm{F}$ & $\%$ & $\mathrm{f}$ & $\%$ \\
\hline Hayatı Kolaylaştırıcı & 41 & 14.3 & 7 & 2.4 \\
\hline Mesleki ve İnsani & 8 & 2.8 & 17 & 6.0 \\
\hline \multicolumn{5}{|l|}{ Roller } \\
\hline Doğanın Sundukları & 25 & 8.7 & 19 & 6.7 \\
\hline Faydalı Eşya & 3 & 1.2 & 33 & 11.5 \\
\hline Organizmada & - & 0 & 1 & 0.4 \\
\hline \multicolumn{5}{|l|}{ Bulunanlar } \\
\hline TOPLAM & 77 & 27 & 77 & 27 \\
\hline
\end{tabular}

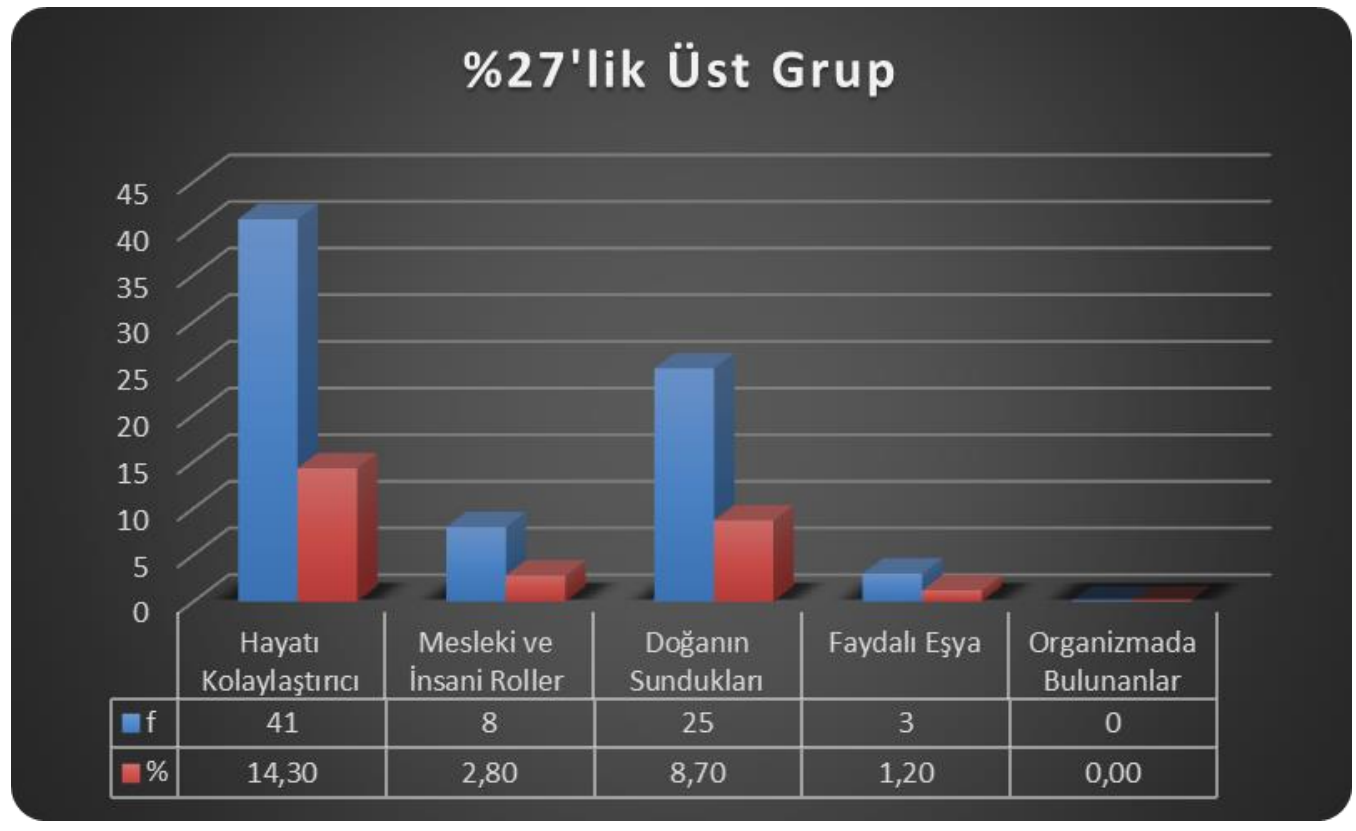

Şekil 1. \%27’lik üst grubun metafor dăğlımının sütun grafiği 


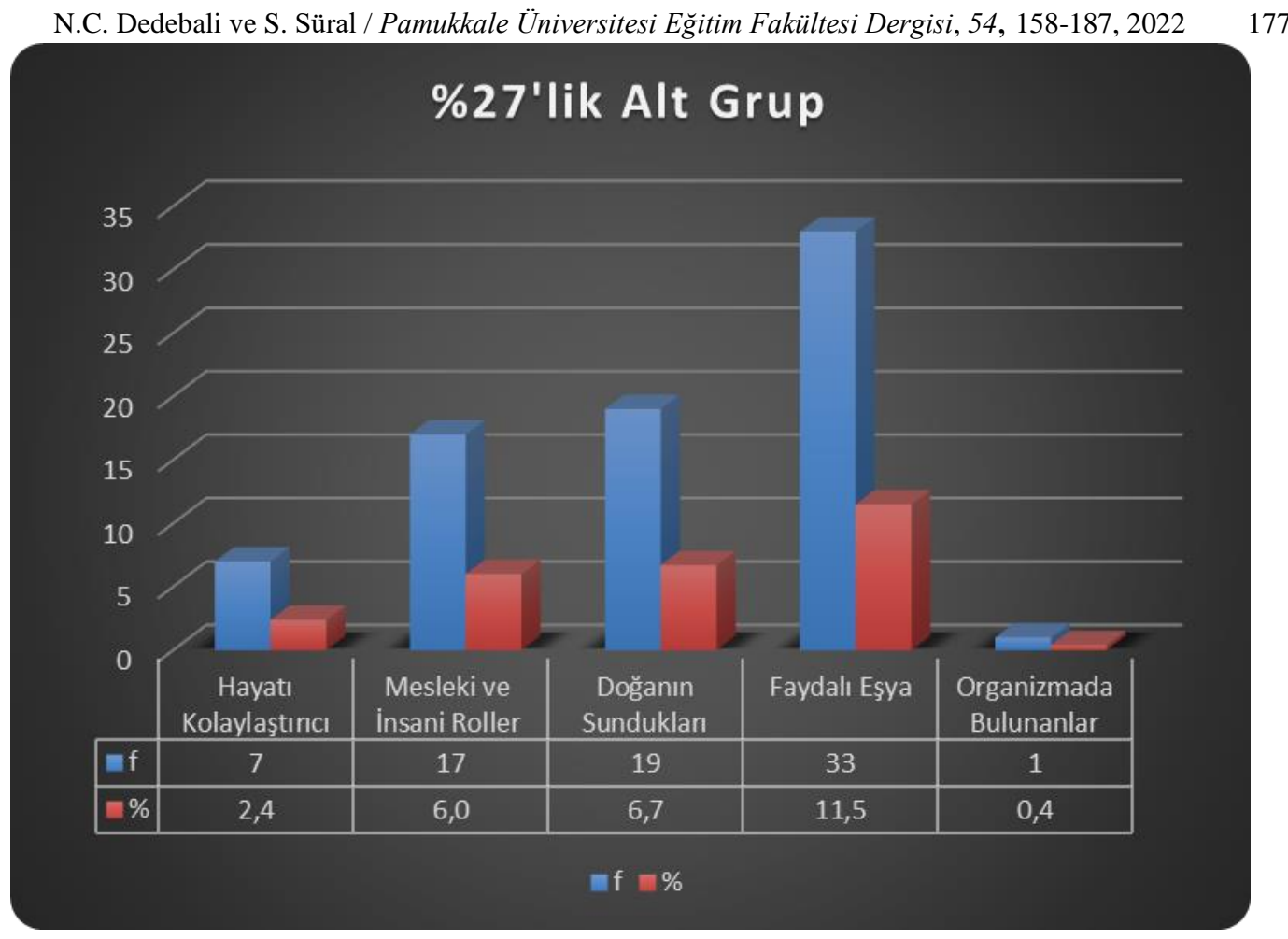

Şekil 2.\%27’lik alt grubun metafor dă̆gllımının sütun grafiği

\section{Tartışma, Sonuç ve Öneriler}

$\mathrm{Bu}$ araştırmada, eğitim fakültelerinde öğrenim gören öğretmen adaylarının öğrenme öğretme anlayış düzeyleri ve metaforik algılarının incelenmesi amaçlanmıştır. Araştırmada elde edilen verilere göre bu çalışma grubunda yer alan öğrencilerin öğrenme ve öğretme anlayışlarının geleneksel anlayışa oranla yapılandırmacı anlayışı daha fazla yansıttığı söylenebilir. Öğretmen adayları ile yapılan bu çalışmada elde edilen sonuç, eğitim fakültelerinde öğretim programlarının hazırlanmasının ve uygulanmasında yapılandırmacı anlayışın temel alınmasından kaynaklanabilir. Bunun yanında Türk Eğitim Sistemi’ne yönelik 15 yıldır uygulanan yapılandırmacı yaklaşımı esas alan eğitimdeki reformların yansıması olarak düşünülebilir.

Araştırmanıı alt amaçlar bağlamında ilk olarak cinsiyet, sınıf düzeyi, branş ve öğretme faaliyeti değişkenlerinin öğretmen adaylarının yapılandırmacı öğrenme öğretme anlayışları üzerinde anlamlı bir fark oluştururken; "öğrenme öğretme anlayışına katkısı en yüksek ders" değişkeninin bir fark oluşturmadığ 1 sonucuna ulaşılmıştır. Cinsiyet değişkeninde grupların aritmetik ortalamaları incelendiğinde, kadın öğretmen adaylarının erkek öğretmen adaylarına oranla öğrenme öğretme anlayışlarının yapılandırmacılığa daha uygun olduğu görülmektedir. Öğretmen adaylarından öğrenme ve öğretme anlayışları alt 
boyutunda cinsiyet değişkende ulaşılan bu sonuçlar ilgili alan yazınla paralellik göstermektedir (Aypay, 2011; Baş, 2014; Oğuz, 2011). Kadın öğretmen adaylarının daha yapılandırmacı bir eğitim anlayışı benimsemiş olmaları bireylerin cinsiyete bakış açısına yönelik sosyo-kültürel ortamları ve ailede geçirilen eğitsel deneyimlerle açıklanabilir. Ancak bunun yanında alan yazın incelendiğinde bazı araştırmalarda cinsiyete göre öğrenme öğretme anlayışlarında anlamlı farklılık gözlenmemiştir (Bağc1, 2019; Bilgin \& Aykac, 2016; Engin \& Daşdemir, 2015; Yaral1, 2019).

Araştırmada elde edilen bulgulara göre öğrenim görülen sınıf düzeyi arttıkça yapılandırmacı eğitim anlayışının düzeyinin yükseldiği görülmektedir. Dördüncü sınıfta öğrenim gören öğretmen adaylarının lehine anlamlı farklılık görülmektedir. Alan yazında öğretmen adaylarıyla yapılan birçok araştırmada sınıf düzeyi arttıkça öğrenme öğretme anlayışları arasında farklılaşma oluştuğu gözlenmiştir (Bıkmaz, 2017; Löfström ve PoomValickis, 2013; Tang vd., 2012). Bu farklılığın temel kaynağı eğitim fakültelerinde yapılandırmacı yaklaşımla hazırlanan ve uygulanan öğretim programlarının öğretmen adaylarının öğrenme öğretme anlayışlarına sağladığı katkıyla açıklanabilir. Nitekim eğitim fakültesinin son yıllarındaki öğretmenlik uygulaması derslerinin öğretmen adaylarının öğrenme öğretme anlayışlarında değişikliğe yol açması beklenebilir.

Araştırmada öğrenim görülen bölüme göre öğrenme öğretme anlayışlarında anlamlı farklılığa rastlanmıştır. Farklılaşmanın kaynağına ilişkin yapılan analizlerde sosyal bilgiler bölümünde öğrenim gören öğretmen adaylarının da çok yapılandırmacı anlayışı benimsedikleri tespit edilmiştir. Bunun yanında öğretmen adaylarının bölüm açısından ortalamaları incelendiğinde Türkçe, sınıf ve fen bilgisi öğretmenliği programlarında öğrenim gören öğretmen adaylarının yapılandırmacı öğrenme öğretme anlayışlarının yüksek olduğu gözlenmiştir. Bunun yanında Oğuz (2011)'un yapmış olduğu bir çalışmada sosyal bilgiler öğretmen adaylarının fen bilgisi öğretmen adaylarından daha yapılandırmacı öğrenme öğretme anlayışını benimsediklerini belirlemiştir. Benzer şekilde iki bölümde yürütülen bir çalışmada sınıf öğretmeni adaylarının fen bilgisi öğretmen adaylarından daha fazla yapılandırmacı öğrenme öğretme anlayışına sahip oldukları belirlenmiştir.

Araştırmada elde edilen verilere göre öğretmen adaylarının öğrenme öğretme anlayışına katkısı en yüksek ders değişkeninin anlamlı bir fark oluşturmadığı sonucuna ulaşılmıştır. Bunun yanında araştırmada verilen öğretmenlik meslek bilgisini kapsayan bütün derslerin öğrenme öğretme anlayışına katkı ortalaması yüksek düzeyde olduğu söylenebilir. Süral (2011)'in sınıf öğretmen adaylarıyla yaptığı bir çalışmada öğretmenlik 
meslek bilgisi derslerinin öğretmen adayları tarafından mesleki açıdan en gerekli dersler olarak görülmesi eldeki araştırma sonuçlarını destekler niteliktedir.

Araştırmada öğretme faaliyeti olarak yapılandırmacı öğrenme öğretme anlayışlarına yönelik bulgularda "materyal kullanma" lehine farklılaşmaya rastlanmışken; geleneksel öğrenme öğretme anlayışına yönelik bulgularda "tahtada ders anlatma” lehine farklılaşmaya rastlanmıştır. Değişen yaşam koşullarına bağlı olarak yeni ihtiyaçlar öğretmenin öğrenme öğretme anlayışları üzerinde oldukça etkili olmuştur. Öğretmen adayları yapılandırmacı öğrenme öğretme anlayışı içinde öğrenciyi aktif kılmayı ve öğrenmede açıklığı artırmak için materyal kullanımını önemsedikleri söylenebilir.

Araştırmaya katılan öğretmen adayları yapılandırmacı öğretmen algılarını açıklamada 79 farklı olmak üzere toplamda 278 metafor üretmişlerdir. Elde edilen bu metaforlarla öğretmen adaylarının yapılandırmacı öğretmen kavramının değişik yönlerine vurgu yaptıkları ortaya çıkmıştır. En sık tekrar eden metaforlar 1şık, rehber, kitap, pusula, güneş, mum, su olarak belirlenmiştir. Bu çalışmada üretilen, pusula, güneş, 1şık, navigasyon ve kitap gibi metaforlar Yıldız'ın (2019) yapılandırmacı öğretmene ilişkin öğretmen adaylarıyla yaptığı metafor çalışmasında da benzer şekilde üretilmiştir. Ayrıca öğretmen kavramına yönelik alan yazındaki metafor çalışmaları incelendiğinde bu çalışmanın metaforlarıyla benzerlik gösteren farklı çalışmaların da yer aldığı görülmektedir. Benzer şekilde, Kıral'ın (2015) yine öğretmen adaylarıyla yaptığı çalışmada öğretmen kavramı için rehber, pusula, anne-baba, güneş, mumu, kutup yıldızı gibi metafor üretilmiştir. Bunun yanında Pehlivan'ın (2010) araştırmasında öğrenciler tarafında öğretmen kavramını daha çok güneş, ebeveyn, 1şık, deniz feneri, pusula gibi metaforlarla ifade edilirken; Ertürk'ün (2017) ilkokul öğrencileriyle yaptığı araştırmada öğretmen kavramına anne, baba, güneş, arı, fener, pusula, kutup yıldızı gibi benzer metaforlar ile ifade edilmiştir. Eldeki araştırmada ve alan yazındaki benzer metafor çalışmalarında öğretmenin yol gösterici rolüne vurgu yapılmaktadır.

Araştırmada elde edilen metaforların analizi sonucunda ulaşılan kategoriler, "hayatı kolaylaştırıcı", "mesleki ve insani roller", "doğanın sundukları”, "faydalı eşya" ve “organizmada bulunanlar” başlıkları altında toplanmıştır. Yıldız'ın (2019) öğretmen adaylarıyla yaptığı bir araştırmada benzer şekilde "yol gösterici/aydınlatıcı öğretmen; bakıcı, sevgi ve şefkat veren öğretmen”, "bilgi kaynağı ve aktarıcısı öğretmen”, "sorun çözücü ve lider öğretmen”, “özerkliği destekleyen ve kontrol eden öğretmen”, “usta öğretmen”, “anlamlı öğrenme ve düşünmeye destek olan öğretmen”, "hayat kaynağı öğretmen”, 
“varlığıyla huzur veren öğretmen”, "özgün şeyler ortaya çıkaran öğretmen” yapılandırmacı öğretmene ilişkin oluşturulan metaforlar 10 kategorileri altında toplanmıştır. Eren ve Tekinarslan'ın (2013) öğretmen adaylarıyla yaptığı araştırmada "seven ve ilgi gösteren bir kişi olarak öğretmen”, “bilginin kaynağı olarak öğretmen” ve "bir rehber olarak öğretmen” olarak öğretmene kavramına ilişkin kategoriler oluşturulmuştur.

Öğretmen adaylarından elde dilin verilere göre oluşturulan kategorilere göre yapılandırmacı öğretmen en çok "hayatı kolaylaştırıcı" özelliği ön plana çıkmaktadır. Öğretmen adayları tarafından hayatı kolaylaştırıcı kategorisinde 1şık, rehber, pusula, mum, yol gösterici, anne, aile, kuzey yıldızı, fener, trafik levhası metaforları üretilmiştir. Yapılandırmacı öğretmen, öğrenme süreçlerinde öğrencilere doğru bilgiyi sunmayan, bilginin aktarımından ziyade doğru bilgiye ulaşmada rehberlik eden, etkinlik planlamada öğrencilerin farklılıkları dikkate alan, yaparak yaşayarak öğrenmenin öğrenmede kalıcılığına inanan kişi olarak tarif edilmiştir.

Küçüktepe ve Gürültü'nün (2014) araştırmasında yapılandırmacı öğretmen sınıf içi etkinlik planlamada öğrenci merkezli, kalıcı öğrenmede yaparak yaşayarak öğrenmeyi benimseyen, bireyler arası farklılıkların bilincinde, öğrenmede öğrenciye yol gösteren ve her an öğrenciye rehberlik yapan kişi olarak ifade edilmiştir. Bu sonuçlar Yıldız (2019), Ocak ve Gündüz (2006), Tuan, Chang, Wang ve Treagust (2000)'in araştırmalarında elde ettikleri araştırma sonuçlarıyla tutarlılık göstermektedir. Hayatı kolaylaştırıcı öğretmen kategorisinde elde dilen bu metaforlardan öğretmen adaylarının yapılandırmacı öğretmen kavramını yüksek oranda iyi algıladıkları sonucu çıkarılabilir.

Mesleki ve insani roller kategorisinde bahçıvan, arkadaş, mühendis, yenilikçi, inşaat ustası, kaşif, dost gibi metaforlar üretilmiştir. Öğretmen adaylarının bu kategoride oluşturdukları metaforlardan yapılandırmacı öğretmeninin, öğrenme sürecini şekillendiren, öğrenme öğretme süreçlerine uygun materyalleri düzenleyen ve öğrenci ilgi ve isteklerini uygun bir biçimde öğrenme etkinliklerini planlayan bir biçimlendirici olarak görüldüğü sonucuna ulaşılabilir. Özden (2003) öğrencilerin öğrenme sürecinde gerçek hayattaki problemlere benzer özellikte problemlere yönelik öğrenme çabasına girerek öğrendiklerini belirtmiştir. Küçüktepe (2003)' e göre yapılandırmacı yaklaşımda öğretmenin rolü, bilgi vermek değil, öğrenciye bilgi inşa etme sürecinde yeni firsat ve motivasyon sağlamaktır. Araştırmada elde edilen metaforlardan öğretmen adaylarının öğretmenin öğrencilerini hayata hazırlama sürecindeki rolünü algıladıkları saptanmıştır. 
N.C. Dedebali ve S. Süral / Pamukkale Üniversitesi Eğitim Fakültesi Dergisi, 54, 158-187, 2022

Araştırmada doğanın sundukları kategorisinde ise güneş, su, altın, çiçek, ağaç, deniz, toprak, okyanus, dağ gibi metaforlar üretilmiştir. Öğretmenin güneş, su, altın gibi doğada yaşam için gerekli maddelerle ilişkili metaforlar oluşturulması öğretmenliğin öğretmen adayları önem verilen meslek olduğu sonucuna ulaşılabilir. Yılmaz, Göçen ve Yılmaz'ın (2013) öğretmen adaylarıyla yaptı̆̆ı bir araştırmada öğretmenliğin saygın bir meslek olarak görülmediği sonucunu ortaya koymuştur. Bunun yanında çok sayıda araştırmada öğretmenlerin sosyo-ekonomik durumlarının iyi olmaması, herkesin yapabileceği bir meslek olarak görülmektedir (Celep, 2004; Ceylan, 2001). Oysaki bir ülkenin öğretmene verdiği aynı zamanda eğitime verdiği değerin göstergesi kabul edilir.

Son olarak öğretmen adaylarının öğrenme öğretme anlayışlarıyla yapılandırmacı öğretmen kavramına ilişkin oluşturdukları metafor arasındaki ilişki incelenmesi amaçlanmıştır. Bu amaç doğrultusunda en yüksek öğrenme öğretme anlayışı puanına sahip \%27'lik dilime giren ve en düşük puana sahip \%27'lik dilime giren öğretmen adaylarının metaforları arasında karşılaştırma yapılmıştır. En yüksek öğrenme öğretme anlayış puanlarına sahip öğretmen adaylarının, hayat kolaylaştırıcı rehber öğretmen kategorisinde metaforlarla yapılandırmacı öğretmeni açıkladıkları görülmüştür. Araştırmanın temel amacı içerisinde belirtilmiş olan yapılandırmacı eğitim anlayışının dayandığı temel felsefe olan pragmatist akımda da belirtildiği gibi bireyin edindiği bilginin günlük hayatta kullanabilemsi, öğrendiği bilgiyi beceriye dönüştürebilmesi düşüncesinden yola çıkılacak olursa; öğrenme öğretme anlayışları yüksek düzeyde olan öğretmen adaylarının pragmatist düşüncenin getirdiği bu temel felsefeyi kavradıkları söylenebilir. Buradan hareketle, doğru bilginin insanoğluna fayda sağlayan bilgi olması, öğretmen adaylarının yapılandırmacı öğrenme anlayışını kavradıkları, öğrencilerini de hayatı kolaylaştıran öğretmen olmayı algılayarak bunu metaforik anlamda araştırmada ifade ettikleri sonucuna ulaşılabilir. Öğrenme öğretme anlayışı en düşük öğretmen adayları ise faydalı eşya kategorisinde metaforlar üretmişlerdir. Sonuç olarak yüksek öğrenme öğretme anlayışına sahip öğretmen adaylarının öğretmen kavramına daha çok bir rehber, 1şık gibi algıladıkları sonucuna ulaşılabilir. Farklı bir açıdan bakarsak öğrenme öğretme anlayışları düşük öğrencilerin öğretmen kavramını öğrenciye sağladığı fayda açısından algıladığı ifade edilebilir.

Sonuç olarak, öğretmen adaylarıdan öğrenme öğretme anlayışı yüksek olanlarda olduğu gibi öğrenme öğretme anlayışı düşük olanlarda da öğretmen kavramına ilişkin olarak yapılandırmacı anlayışla ilişkili metaforlar elde edilmiştir. $\mathrm{Bu}$ bağlamda öğretmen adaylarının öğrenme öğretme anlayışlarının belirlenmesi ve yapılandırmacı öğretmen 
kavramına ilişkin geliştirmiş oldukları metaforlar onların ileride mesleklerini nasıl algıladıklarını açıklamada önemli sonuçlar ortaya koyduğu söylenebilir. Öğretmen adaylarının görev alacakları mesleğe yönelik algıları onların ileride benimseyecekleri öğrenme ve öğretme algılarını hiç şüphesiz etkileyeceğinden konunun önemini bir kat daha artırmaktadır. Gelecek araştırmalarda, metaforlar inceleme yoluyla farklı zamanlarda öğretmen adaylarının yapılandırmacı öğretmene yükledikleri anlamlardaki değişim incelenebilir. Yine öğretmen adaylarının öğrenme öğretme anlayışları ve metaforik algılarının belirlenmesinin amaçlandığı bu çalışmanın benzerini farklı branş ve kıdemlerdeki öğretmenlerle de yapılarak meslek öncesi ile meslek sürecindeki algıları ve metaforları karşılaştırılabilir. Böylelikle öğretmenlik mesleğinin derinlemesine değerlendirilmesi amacıyla daha geniş kitlelerden veri toplanarak bu konuda genellenebilir sonuçlara ulaşılabilir.

Etik Kurul İzin Bilgisi: Bu kısımda Bu araştırma, Sosyal ve Beşeri Bilimleri Bilimsel Araştırma ve Yayın Etiği Kurulunun 10/02/2021 tarihli 68282350/2018/G03 sayılı kararı ile alınan izinle yürütülmüşı̈̈r.

\section{Yazar Çıkar Çatışması Bilgisi}

Yazarlar arasında araştırma sürecinde herhangi bir çıkar çatışması yaşanmamıştır.

\section{Yazar Katkısı}

Araştırmanın birinci yazarı Doç. Dr. Nurhak Cem DEDEBALİ araştırmanın veri toplama kısmında, araştırmanın amacının belirlenmesinde ve sürecin yönetilmesinde katkı sağlamıştır. Ayrıca yazar, araştırmanın tartışma, sonuç ve öneriler kısmını yazmıştır.

Araştırmanın ikinci yazarı Doç. Dr. Serhat SÜRAL araştırmanın veri toplama kısmında, araştırmanın amacının belirlenmesinde ve sürecin yönetilmesinde katkı sağlamıştır. Ayrıca yazar, araştırmanın giriş, yöntem ve bulgular bölümlerini yazmıştır. 


\section{Kaynakça}

Akar, H. ve Yıldırım, A (2004). Oluşturmacı öğretim etkinliklerinin sınıf yönetimi dersi'nde kullanılması: bir eylem araştırması, İyi Örnekler Konferansı, 1 -15, İstanbul.

Arslan, M. M. ve Bayrakçı, M. (2006). Metaforik düşünme ve öğrenme yaklaşımının eğitimöğretim açısından incelenmesi. Milli Eğitim Dergisi, 35(171), 100-108.

Aydın, H. (2007). Felsefi temelleri işığında yapılandırmacılık, Ankara: Nobel Yayın.

Aydın, S. İ. ve Pehlivan, A. (2010). Türkçe öğretmeni adaylarının “öğretmen” ve "öğrenci” kavramlarına ilişkin kullandıkları metaforlar. International Periodical For the Languages, Literature and History of Turkish 5(3) 818-842.

Aypay, A. (2011). Öğretme ve öğrenme anlayışları ölçeği’nin Türkçe uyarlaması ve epistemolojik inançlar ile öğretme ve öğrenme anlayışları arasındaki ilişki. Kuram ve Uygulamada Ĕ̈itim Bilimleri, 11(1), 7-29.

Bağcı, H. (2019). İlköğretim matematik öğretmeni adaylarının öğretme-öğrenme anlayışları ile teknopedagojik eğitim yeterlikleri arasındaki ilişki. Pesa International Journal of Social Studies, 5(1), 1-9.

Bakır, K. (2006). Pragmatizm ve eğitime yansımaları. Atatürk Üniversitesi Kazım Karabekir Ĕ̈itim Fakültesi Dergisi, (14), 49-68.

Baki, A. ve Gökçek, T. (2012). Karma Yöntem Araştırmalarına Genel Bir Bakış. Elektronik Sosyal Bilimler Dergisi, 11(42), 1-21.

Baş, G. (2014). İlköğretim öğretmenlerinin öğrenme öğretme anlayışlarının bazı değişkenler açısından değerlendirilmesi. Dicle Üniversitesi Ziya Gökalp Eğitim Fakültesi Dergisi, (22), 18-30.

Bıkmaz, F. (2017). Öğretmen adaylarının öğretme-öğrenme anlayışları ve bilimsel epistemolojik inançlarının araştırılması: Boylamsal bir çalışma. Eğitim ve Bilim, 189, 183-196.

Bilgin, H. ve Aykac, N. (2016). Pre-Service teachers' teaching-learning conceptions and their attitudes towards teaching profession. Educational Process: International Journal, 5(2), 139-151. 
Can, Ş. ve Çelik, C. (2018). Fen bilgisi ve sınıf öğretmeni adaylarının öğretme-öğrenme anlayışlarının incelenmesi. Afyon Kocatepe Üniversitesi Sosyal Bilimler Dergisi, 20 (1), 327-339.

Creswell, J. W. (2003). Research design: Qualitative, quantitative, and mixed methods approaches (2nd ed.). Thousand Oaks, CA: Sage.

Değermencioğlu, Ç. (2000). Eğitimin felsefi temelleri: eğitim felsefe ilişkisi: eğitim felsefesi. L. Küçükahmet (Ed.), Öğretmenlik Mesleğine Giriş (3. Baskı) İçinde (S. 81-96). Ankara: Nobel Yayın Dağıtım.

Demirel, Ö. (2008). Yapılandırmacı Eğitim. Ĕ̆itim ve Öğretimde Çă̆daş Yaklaşımlar Seтроzуити, 03-04 Nisan 2008. İstanbul: Harp Akademileri Basımevi.

Draaisma, D. (2000). Metaphors of memory: A history of ideas about the mind. Cambridge University Press.

Engin, G. ve Daşdemir, İ. (2015). Sınıf öğretmenlerinin öğretme ve öğrenme anlayışlarının çeşitli değişkenler açısından incelenmesi. The Journal of Academic Social Sciences Studies, (33), 425-432.

Eren, A.; Tekinarslan, E. (2013). Öğretmen, öğretme, öğrenme, öğretim materyali ve değerlendirmeye ilişkin metaforlar: Yapısal bir analiz. Gaziantep University Journal of Social Sciences, 12(3), 443-467.

Ertürk, R. (2017). İlkokul öğrencilerinin “öğretmen” kavramına ilişkin metaforik algıları. EUluslararası Eğitim Araştırmaları Dergisi, 8(3), 1-15.

Fer, S. \& Cırık, İ. (2007). Yapılandırmacı öğrenme-kuramdan uygulamaya. İstanbul: Morpa Yayınları.

Gall, J. P., Gall, M. D. \& Borg, W. R. (1999). Applying educational research: A practical guide. Longman Publishing Group.

Göğebakan Yıldız, D. (2017). Eğitimde program geliştirme dersine yönelik tutum ve metaforik algıların incelenmesi. 4. Uluslararası Eğitim Programları ve Öğretim Kongresi.

Kazu, H. (2002). Ĕğitim ve Felsefe. M. Taşpınar (Ed.), Öğretmenlik Mesleği İçinde (S.6482). Elazı̆̆g: Elazı̆̆ Üniversitesi Yayınevi. 
N.C. Dedebali ve S. Süral / Pamukkale Üniversitesi Eğitim Fakültesi Dergisi, 54, 158-187, 2022185

Kıral, E. (2015). Öğretmen adaylarının algılarına göre öğretmen metaforları. Adnan Menderes Üniversitesi Ĕ̆itim Fakültesi Eğitim Bilimleri Dergisi, 6(1), 57-65.

Küçüktepe, C. (2003). Pedagojik konstruktivist etkinliklerle işlenen derslerin eleştirel düşünmeye ve kalıcılı̆̆a etkisi. Yayınlanmamış Doktora Tezi, Abant İzzet Baysal Üniversitesi, Sosyal Bilimler Enstitüsü, Bolu.

Küçüktepe, S. E. ve Gürültü, E. (2014). Öğretmenlerin" yapılandırmacı öğretmen" kavramına ilişkin algılarına yönelik metafor çalışması örneği. Abant İzzet Baysal Üniversitesi Eğitim Fakültesi Dergisi.

Lakoff, G. \& Johnson M. (2005). Metaforlar hayat anlam ve dil (Çeviren: Gökhan Yavuz Demir). İstanbul: Paradigma Yayıncılı.

Löfström, E. \& Poom-Valickis, K. (2013). Beliefs about teaching: persistent or malleable? A longitudinal study of prospective teachers' beliefs. Teaching and Teacher Education, (35), 104-113.

Marlowe, B. A. \& Page, M. L. (2005). Creating and sustaining the constructivist classroom. Corwin Press.

Morgan G. (1998). Yönetim ve örgüt teorilerinde metafor (Çev. G. Bulut). İstanbul: BZD Yayınc1lik.

Ocak, G. ve Gündüz, M. (2006). Eğitim fakültesini yeni kazanan öğretmen adaylarının öğretmenlik mesleğine giriş dersini almadan önce ve aldıktan sonra öğretmenlik mesleği hakkındaki metaforlarının karşılaştırılması. Afyon Kocatepe Üniversitesi Sosyal Bilimler Dergisi, 8(2), 293- 310.

Oğuz, A. (2011). Öğretmen adaylarının demokratik değerleri ile öğretme ve öğrenme anlayışlarının incelenmesi. Değerler Ĕ̈itimi Dergisi, 9(22), 139-160.

Öğülmüş, S. (1991). İçerik analizi. Ankara Üniversitesi Eğitim Bilimleri Fakültesi Dergisi, 24(1), 213-228.

Özden, Y. (2003). Öğrenme ve Öğretme. Ankara:Pegem Yayınları.

Perkins, D. (1999). The Many Faces Of Constructivism. Educational Leadership, 57(3), 611. 
Saban, A, Koçbeker, B. N. ve Saban A. (2006). Öğretmen adaylarının öğretmen kavramına ilişkin algılarının metafor analizi yoluyla incelenmesi. Kuram ve Uygulamada Eğitim Bilimleri, 6(2), 461-522.

Saban, A. (2008). Okula ilişkin metaforlar. Kuram ve Uygulamada Ĕgitim Yönetimi. 55, 459-496.

Saban, A. (2004). Giriş düzeyindeki sınıf öğretmeni adaylarının öğretmen kavramına ilişkinileri sürdükleri metaforlar. Türk Eğitim Bilimleri Dergisi, (2), 135-155.

Süral, S. (2015). Sınıf öğretmenliği öğretmen adaylarının öğretmen yetiştirme programındaki derslerin gerekliliği ve işe vurukluk düzeyleri hakkındaki görüşleri. Trakya Üniversitesi Ĕ̈itim Fakültesi Dergisi, 5(1), 34-43.

Şaşan, H. H. (2002). Yapılandırmacı öğrenme yaklaşımı. Yaşadıkça Eğitim. 74(75), 49-52.

Tanberkan, H. (2015). İçerik Analizinde Geçerlik ve Güvenirlik, [Çevrimiçi: https://prezi. com/yrhdpwinv3a/icerik-analizinde-gecerlik-ve-guvenirlik/]. Erişim Tarihi, 23.

Tang, S. Y. F., Wong, A. K. Y. \& Cheng, M. M. H. (2012). Professional learning in initial teacher education: Vision in the constructivist conception of teaching and learning. Journal of Education for Teaching: International Research and Pedagogy, 38(4), 435-451.

Tuan, H. L., Chang, H. P., Wang, K. H., \& Treagust, D. F. (2000). The development of an instrument for assessing students' perceptions of teachers' knowledge. International Journal of Science Education. 22(4), 385-398.

Vadeboncoeur, J. A. \& Torres M. N. (2003). Constructing and reconstructing teaching roles: a focus on generative metaphors and dichotomies. Discourse: Studies in the Cultural Politics of Education, 24(1), 87-103.

Wheatley, G.H. (1991). Constructivist perspectivest on sciences and mathematics learning. Science Education, 75(1), 9-21.

Yaralı, D. (2019). Öğretmen adaylarının öğrenme öğretme anlayışlarının çeşitli değişkenler açısından incelenmesi. Turkish Studies, 14(4), 2869-2887.

Yıldırım, A. ve Şimşek, H. (2008). Sosyal bilimlerde nitel araştırma teknikleri. Ankara, Turkey: Seçkin Yayınevi. 
Yıldız, H. (2019). Öğretmen adaylarının yapılandırmacı öğretmen ve sınıf ortamına yönelik görüşlerinin metafor analizi ile incelenmesi. Turkish Studies, 14(4), 1971-1994.

Yurdakul, B. (2005). Yapılandırmacılık. Demirel, Özcan (Editör), Eğitimde Yeni Yönelimler, Pegem A Yayıncılık, Ankara: (39- 61). 


\title{
Investigation of the Levels of Teaching and Learning Conceptions and Metaphorical Perceptions of Pre-service Teachers
}

\author{
Nurhak Cem DEDEBALİ* Serhat SÜRAL ${ }^{* *}$
}

- Received: 04.01.2021 • Accepted: 01.07.2021 • Online First: 01.07.2021

\begin{abstract}
This study aims to investigate teaching and learning conceptions of pre-service teachers considering primarily their experiences, self-efficacy, perspectives on the world and education, and their individual differences, and to identify metaphors produced by pre-service teachers according to their perspectives on the constructivist learning approach, and thus to determine their general perceptions on this matter. In the study, a mixed-method, which involves using qualitative and quantitative data collection methods to present, analyze and integrate the findings and the separate results in the overall interpretation, was employed. The study was conducted with 284 pre-service Classroom, English, Turkish, Mathematics, Science, and Music teachers studying at universities in different regions of Turkey in the 2019 - 2020 academic year. Within the scope of the research, the Teaching and Learning Conceptions Questionnaire developed by Chan and Elliot (2004) was used to determine the learning-teaching conceptions of pre-service teachers. As a result of the study, the metaphors produced by the pre-service teachers were divided into the conceptual categories as "Facilitating Life", "Professional and Human Roles", "What Nature Offers", "Useful Items," and "What Are Found in the Organism".
\end{abstract}

Keywords: Constructivism, Traditional Approach, Metaphor, Pre-service Teacher

\section{Cited:}

Dedebali, N.C., \& Süral, S. (2022). Investigation of the levels of teaching and learning conceptions and metaphorical perceptions of pre-service teachers. Pamukkale University Journal of Education,54, 158-187.doi:10.9779.pauefd.853592

\footnotetext{
* Assoc. Prof., İzmir Katip Celebi University, 0000-0002-6627-1132, dedebali40@hotmail.com

** Assoc. Prof., Pamukkale University, 0000-0001-9601-3954, ssural@ pau.edu.tr
} 


\section{Introduction}

Although it is a well-known fact that the incorporation of objectives, determined by the needs of the society, the Individual, and the subject area and synthesized through certain educational stages, into the curriculum as achievements plays a crucial part in the curriculum development process, the more important thing is the question of how these identified achievements will be displayed in behavior. Because creating a permanent change in behavior means revealing learned behavior. With the transformation of acquired knowledge into behavior through experiences, the constructivist approach concentrates on the functionality of these behaviors in the individual's daily life. The fact that the pragmatist view, which is also influenced by the constructivist approach, regards knowledge as the true knowledge that benefits the Individual (Değirmencioğlu, 2000; Kazu, 2002; Bakır, 2006) once again reminds us to turn the knowledge into a skill.

Constructivism has started to improve as a theory of how the learners learn the knowledge and then has become an approach that recognizes learners construct new knowledge over time. According to the philosophy of the constructivist approach, the learner configures and puts into practice what they learn, not the repetition of knowledge, but the transfer and restructuring of knowledge (Perkins, 1999). In the constructivist theory, individuals are expected to produce knowledge rather than consume it. . Individual, who is requested by the contemporary world, does not accept the knowledge which is transferred himself-herself directly and without changing. The Individual takes part actively in the process of creating of mean by interpreting (Yıldırım and Şimşek, 1999). As articulated by various scholars, it can be contended that traditional learning environments where the transfer of a read-made knowledge system is used, and students receive the information passively are no longer acceptable in modern education. On the other hand, the constructivist learning approach, which aims to teach students problemsolving skills and trigger students to use higher-order thinking skills, reflects the $21 \mathrm{st}$ century's learning much better.

As Yurdakul (2005) quoted, learning in constructivism is seen as a meaning-making process, and that meaning is created by the learner rather than through instruction. In a similar vein, Akar and Yıldırım (2004) acknowledged that constructivist learning theory needs students' active participation inside and outside the classroom; in this learning process, the student understands the importance of taking responsibility and participating in decision- making and behaves accordingly. When an individual learns, s/he helps to 
construct new knowledge by sharing past knowledge and experiences using the methods of discussion and reflection. Siebert (2005), on the other hand, admitted that the perception of rationality also changes with social changes during the course of life; therefore, instead of definite learning, the learning program is sufficiently flexible to permit development along the lines of student inquiry in the constructivist learning approach. In constructivist teaching, the teacher is entrusted with the task of organizing, managing, and guiding the process; students take primary responsibility for their learning process (with the teacher). In this respect, constructivist learning is a decision-making period that includes the student's abilities, motivations, attitudes, and the things they obtain from their experiences (Şaşan, 2002). From a constructivist perspective, where student-centered teaching replaces teachercentered teaching as opposed to the traditional approach, the idea that the effectiveness of teacher-student interaction should be improved is more emphasized. It is also important to note that the teacher is the one who organizes and creates a classroom environment and implements classroom management practices. Marlowe and Page (2005) stated that in a constructivist class, the teacher should help learners monitor their own progress, prepare checklists for learning and quality work, and prepare self-improving plans. While distinguishing a constructivist teacher from a traditional teacher, Aydin (2007) defines the teacher in contemporary education as a guide who encourages teaching, a person who knows the importance of experience and prior knowledge in learning, and who creates learning and teaching environments that take creative, critical and analytical thinking into account rather than transferring ready-made knowledge.

Constructivist teachers guide students to make sense of new knowledge, encouraging them to research and analyze. S/he prepares a suitable learning environment considering students' differences. Constructivist teachers help students reconstruct knowledge by supporting their ability to generate hypotheses and make different interpretations. Teachers' perspectives on the constructivist teacher, in other words, their affective characteristics regarding the constructivist teacher will indirectly affect the teaching practices (Küçüktepe \& Gürültü, 2014). Since traditional teachers ignore the affective traits of students and start the lesson without paying attention to the introductory behaviors that students can develop affectively, students' motivation may adversely be influenced. On the contrary, the constructivist theory claims that the students should be treated as a whole. With this in mind, while instructing, the teacher begins to plan a holistic evaluation by following students' development in the learning process. 
Demirel (2008) defines a teacher with constructivist understanding as; open-minded, contemporary, self-renewal, considering individual differences, providing appropriate learning experiences, and learning with learners. Fer and Curık (2007), on the other hand, emphasize internalizing constructivism which supports subjective knowledge and designing learning environments accordingly. In this context, a teacher with a positivist teaching style should not be expected to exhibit constructivist roles in practice. Therefore, a teacher who internalizes the constructivist approach in which s/he assumes multiple roles, breaking with traditional methods such as transferring the knowledge, classroom management, and evaluating academic success as a product, should be seen as the necessity of modernity innovation and pragmatist thinking. Given that a teacher, who is perhaps the most fundamental component of the teaching process, has many roles, it is significant to identify perceptions of teachers who are inclined to use constructivist or traditional teaching approaches.

In this context, identifying pre-service teachers' metaphorical perceptions of teaching and learning in line with the knowledge they have acquired in the teacher training program and experiences they have gained under the roof of the faculty of education and outside their immediate environment will eventually update and shape the roles assigned to them. When it comes to the concept of metaphor, Arslan and Bayrakçı (2006) define it as " a powerful mind mapping and modeling mechanism towards individuals' understanding and configuring their worlds" and Morgan (1998) states that the use of metaphor implies "a way of thinking and a way of seeing that pervade how we understand our world generally". In this sense, metaphor is a powerful cognitive tool that an individual can use to understand and explain a highly abstract, complex, or theoretical phenomenon.

Metaphor is creative; because it directs our minds to new similarities, relationships, and views that they have created themselves, going beyond existing and obvious similarities, relationships, and views (Lakoff and Johnson, 2005). Metaphors take words from their usual context and move them to a different context. Additionally, metaphors reflect a period, a culture, an environment and provide information relating to activities and thoughts of its users (Draaisma, 2000).

Metaphors can be used in teacher education to direct teaching practices and define teachers' place in modern educational approaches (Vadeboncoeur \& Torres, 2003). Thus, if an educator wishes to make a pedagogical change in line with his/her teaching goals, values, or philosophy, that educator should first review the current situation. In this respect, 
metaphor emerges as the most appropriate mental model. Because whether we are aware of it or not, whether we accept it or not, metaphors continue to live with us as a mental model (Saban; Koçbeker; Saban, 2006). Given the need for more qualitative and quantitative research (Saban, 2004) that investigates the attitudes of the pre-service teachers towards their teachers in the past and their views of an ideal teacher, this research is of vital importance as it aims to assess learning and teaching conceptions of pre-service teachers considering their experiences, their self-efficacy, their perspectives on the world and education, and their differences, and to produce metaphors according to their perspectives on the constructivist education approach, and thus to identify their general perceptions on this matter.

This study aims to determine the levels of teaching and learning conceptions and metaphorical perceptions of pre-service teachers studying at faculties of education of various universities. Specifically, the study sought to answer the following sub-problems:

1. Do teaching and learning conceptions of pre-service teachers differ according to gender, grade level, and department variables?

2. Which metaphors do pre-service teachers produce to explain their constructivist teaching approach?

3. Do the pre-service teachers' metaphors of constructive learning differ according to their conceptions of teaching and learning?

\section{Methodology}

This section entails the research model, the number of participants, characteristics of variables, data collection tools, and reliability and validity analysis results.

\section{Research Model}

In the study, a mixed-method, which involves the use of both qualitative and quantitative data collection methods to present, analyze and integrate the findings and the separate results in the overall interpretation, was employed. In approaching mixed methods research, researchers use six mixed methods design strategies which include sequential explanatory, sequential exploratory, sequential transformative, concurrent triangulation, concurrent nested and concurrent transformative (Creswell, 2003). The concurrent triangulation approach is deemed to be the most appropriate method for this study. In this approach, qualitative and quantitative data are collected concurrently. Data analysis is 
done separately. While interpreting the data, it is intended to assess how close the qualitative and quantitative data are to each other (Baki and Gökçek, 2012).

\section{Participants}

The study was carried out with a total of 284 pre-service Classroom, English, Turkish, Mathematics, Science and Music teachers studying at universities in different regions of Turkey in the 2019 - 2020 academic year. Simple random sampling method was applied in the study. Simple random sampling method is a process in which every Individual in the sampling frame (i.e., desired population) has an equal and independent chance of being chosen for the study (Gall., Gall, Borg, 1999).

\section{Data Collection Tools}

"The Teaching and Learning Conceptions Questionnaire" was developed by Chan and Elliot (2004) in this study, which aims to determine the teaching and learning conceptions of preservice teachers within the scope of the research. This study was carried out with 385 volunteer pre-service teachers in Hong Kong. The scale, which was later adapted into Turkish by Aypay (2011), was divided into two sub-dimensions: constructivist and traditional. The sub-dimension of the constructivist approach was composed of 12 items, and the sub-dimension of the traditional approach was composed of 18 items. The thirtyitem scale was subjected to Confirmatory Factor Analysis, and GFI value has been found as 0,93, AGFI value as $0,91, \mathrm{RMR}$ value as 0,50 and RMSEA value as 0,54 
Table 1. Distribution of the Sample Group by Variables

\begin{tabular}{|c|c|c|c|c|c|}
\hline Variable & Group & $\mathrm{f}$ & & & $f$ \\
\hline \multirow[t]{2}{*}{ Gender } & Female & 237 & \multirow{8}{*}{$\begin{array}{l}\text { The Course } \\
\text { with the } \\
\text { Highest } \\
\text { Contribution }\end{array}$} & $\begin{array}{ll}\text { Introduction } & \text { to } \\
\text { Education Science } & \end{array}$ & 6 \\
\hline & Male & 47 & & Education Psychology & 32 \\
\hline \multirow[t]{3}{*}{ Grade Level } & 2nd Grade & 101 & & $\begin{array}{l}\text { Teaching Principles and } \\
\text { Methods }\end{array}$ & 74 \\
\hline & 3rd Grade & 111 & & $\begin{array}{ll}\text { Assessment } & \text { and } \\
\text { Evaluation } & \end{array}$ & 7 \\
\hline & 4th Grade & 72 & & $\begin{array}{l}\text { Instructional } \\
\text { Technology and } \\
\text { Material Design }\end{array}$ & 14 \\
\hline \multirow{8}{*}{ Department } & Classroom Teaching & 32 & & $\begin{array}{l}\text { Special Teaching } \\
\text { Methods }\end{array}$ & 51 \\
\hline & Science Teaching & 44 & & Teaching Practice & 96 \\
\hline & $\begin{array}{l}\text { Mathematics } \\
\text { Teaching }\end{array}$ & 132 & & $\begin{array}{l}\text { Curriculum } \\
\text { Development } \\
\text { Education }\end{array}$ & 4 \\
\hline & English Teaching & 22 & \multirow{5}{*}{$\begin{array}{l}\text { Teaching } \\
\text { Activity }\end{array}$} & Readiness Level & 27 \\
\hline & $\begin{array}{ll}\text { Social } & \text { Science } \\
\text { Teaching } & \end{array}$ & 13 & & $\begin{array}{l}\text { Using the Board in } \\
\text { Teaching }\end{array}$ & 11 \\
\hline & Turkish Teaching & 13 & & Using material & 50 \\
\hline & Music Teaching & 28 & & $\begin{array}{l}\text { Engaging Students in } \\
\text { Learning }\end{array}$ & 187 \\
\hline & & & & Problem Solving & 9 \\
\hline
\end{tabular}

- The compliance indices obtained as a result of confirmatory factor analysis confirm that the scale development process is successful. In the second part, research data were collected via metaphor identification form where pre-service teachers completed the statement "Teacher is like ; because 


\begin{tabular}{|c|c|c|c|}
\hline & & $\begin{array}{c}\text { Turkish } \\
\text { Adaptation } \\
\text { Study } \\
\text { (Aypay,2011) }\end{array}$ & $\begin{array}{l}\text { Sample } \\
(\mathrm{N}=209)\end{array}$ \\
\hline $\begin{array}{l}\text { The Sub-dimension of Constructivist } \\
\text { Approach }\end{array}$ & 12 Items & .86 & .947 \\
\hline $\begin{array}{l}\text { The Sub-dimension of Traditional } \\
\text { Approach }\end{array}$ & 18 Items & .84 & .905 \\
\hline Total & 30 Items & .84 & .895 \\
\hline
\end{tabular}

Given the scales are to be used, the level of reliability for preliminary test is expected to be 0.60 as it is 0.80 for fundamental studies. On the other hand, reliability level for practical studies should range between 0.90 and 0.95 (Şencan, 2005). While reliability confidence varies according to research types in social sciences, reliability confidence for scientific studies is expected to be 0.70 , and the level of 0,85 is expected for studies based on ability, interest, and skill (Şencan, 2005). According to the results of the reliability analysis of the Turkish adaptation study, where all items were included, the Cronbach Alpha value was found to be .84 . In contrast, the result of the reliability analysis of the actual study indicated a Cronbach alpha value of .895 . We can thus contend that the scale can be used as a reliable measurement tool. On the other hand, given the reliability coefficients of the subdimensions, we can generally imply that reliable coefficients were obtained from the sample group

\section{Data Collection and Analysis}

The "Teaching and Learning Conceptions Questionnaire" and the metaphor question were concurrently submitted to the pre-service teachers. The data was collected online via Google Form. The mean and standard deviation in descriptive statistics were first calculated to analyze the quantitative data obtained. Afterward, the Kolmogorov-Smirnov normality test was administrated to independent variables. The results indicated a nonparametric distribution. Subsequently, Mann Whitney U, Kruskal Wallis H, Dunnett's C tests were performed to identify a significant difference in the pre-service teachers' conceptions of teaching and learning.

The content analysis method was used for the analysis of qualitative data. Content analysis is to bring together similar data within the framework of certain concepts and 
themes and interpret them in a way that the reader can understand (Yıldırım \& Şimşek, 2008). Further, metaphor analysis was performed according to Saban's (2008) metaphor analysis stages.

$\checkmark \quad$ Coding and Elimination: In this stage, the metaphorical images used by preservice teachers to explain Curriculum Development in Education course were coded. Subsequently, it was examined whether the metaphor could be clearly associated with the course of Curriculum Development in Education, and the expressions believed to have metaphoric characteristics were listed. It was observed that metaphors were generated in all the collected data. Furthermore, pre-service teachers developed similar metaphors.

Sample metaphor compilation and categorization: The 209 metaphors produced and pre-service teachers' explanations were reviewed and it was intended to understand how the pre-service teachers perceived the concept of "teacher". Metaphors were analyzed in terms of "the relationship between the subject of the metaphor and its source". As a result of the content analysis, a total of ...... categories associated with similar metaphors emerged.

$\checkmark \quad$ Reliability and Validity: All metaphors created by the participants were listed. Experts' opinions were taken regarding the metaphors and categories developed based on the pre-service teachers' statements. For reliability, Tanberkan (2015) states that the reliability of content analysis is related to coding, and developing clear and understandable categories through coding is one of the indicators of reliability. In terms of the reliability of the content analysis, Öğmüş (1991) stresses the importance of identifying and clearly defining categories in advance so that different observers can observe the same phenomena on the same material. For this reason, the metaphors of researchers which were obtained independently of each other were coded and categorized. Upon the completion of analyses, similar coding and category names were detected. Although the validity of the research is related to its reliability, reliability alone is not a sufficient criterion for validity. According to Yıldırım and Şimşek (2008), the validity in qualitative analysis is heavily based on the objective analysis of the researchers and reporting the collected data in a detailed way and explaining how the research results are achieved are among important criteria of validity. This study is considered valid since the data collection, the categorization and the results were reported in detail. 


\section{Findings}

This section presents analysis performed to seek answers to sub-problems of the research along with the data obtained from these analysis.

The Pre-service Teachers' Perceived Levels of Teaching and Learning Conceptions According to the Variables Identified

The first sub-problem of the research sought to identify whether the independent variables identified had a significant effect on pre-service teachers' conceptions of teaching and learning.

Table 3. K-S Test Administrated to the Variables Identified

\begin{tabular}{l|c|c|c}
\hline & \multicolumn{3}{|c}{ Kolmogorov-Smirnov } \\
& \multicolumn{3}{|c}{$\begin{array}{c}\text { Degrees of } \\
\text { Freedom }\end{array}$ Significance Level } \\
\hline Gender & .506 & 284 & .000 \\
Grade Level & .232 & 284 & .000 \\
Department & .325 & 284 & .000 \\
The Course with the Highest & .233 & 284 & .000 \\
Contribution & .387 & 284 & .000 \\
Teaching Activity & & & \\
\hline
\end{tabular}

The Kolmogorov-Smirnov (K - S) normality test is used to assess whether the variables are normally distributed. If the data is normally distributed, parametric tests are used, if not, nonparametric tests are used. Nonparametric tests are used when the " $p$ " value is significant at $0.05(p<0.05)$. If " $p$ " value is $p>0.05$, parametric tests should be used (Can, 2014, p.89). Thus, Kolmogorov-Smirnov test was performed and nonparametric tests were used since it indicated a significant difference at the .05 level in all variables.

The Significance Level of the Pre-service Teachers' Teaching and Learning Conceptions According to the Variables Identified (The Sub-dimension of Constructivist Approach)

The objective of the first sub-problem of the research is to identify whether the independent variables identified have a significant effect on pre-service teachers' learning-teaching conceptions. As mentioned previously, the scale consists of two sub-dimensions. Thus, the 
sub-dimension of constructivist approach was first analyzed so that it was intended to measure the effect of the variables on the pre-service teachers' conceptions of teaching and learning.

From the Table 4, it is seen that while the gender, grade level, department and teaching activity, among the independent variables, had a significant effect on pre-service teachers' constructivist conceptions of teaching and learning, the variable of "the course with the highest contribution" did not have any significant effect.

When the gender variable is examined, it is observed that the mean rank of the female pre-service teachers 148.4 (U: 4149.0; Z: -2.771) are higher than the mean rank of the male pre-service teachers 112.2 (U: 4149.0; Z: -2.771). Thus, it can be contended that the female pre-service teachers' conceptions of teaching are more inclined to the constructivist approach than male pre-service teachers.

The grade level variable also yielded significant difference. However, since there are more than 2 sub-groups in the variable, Kruskall Wallis analysis was followed by Dunnet T3 post hoc test whereby it was intended to detect significant differences between groups. Accordingly, significant difference was found between the 2nd graders and the 4th graders. Furthermore, this significant difference was found to be in favor of the 4th graders.

Given the significance levels of the department variable on the constructivist teaching conceptions of the pre-service teachers, it is seen that there is a significant difference at the level of 0.05. Similarly, when Dunnet T3 post hoc test was applied, significant differences were found between 3 different subgroup as follows: Science and Social Studies Teaching, Mathematics and Social Studies Teaching, and Music and Social Studies Teaching. It is important to note that the significant difference in all comparisons is in favor of pre-service social studies teachers.

When it comes to "Teaching Activity", the last independent variable of the research, as provided in Table 4, significant differences were detected between "Readiness levels and Using Materials" and "Using Materials and Solving Problems" sub-groups. Given the mean rank of the groups, the significant difference between the two sub-groups is in favor of the “"Using Materials" in the sub-dimension of teaching activity. 
N. C. Dedebali \& S. Süral / Pamukkale University Journal of Education, 54, 158-187, 2022

169

Table 4. The Differentiation Level of the Variables Identified on the Constructivist Approach

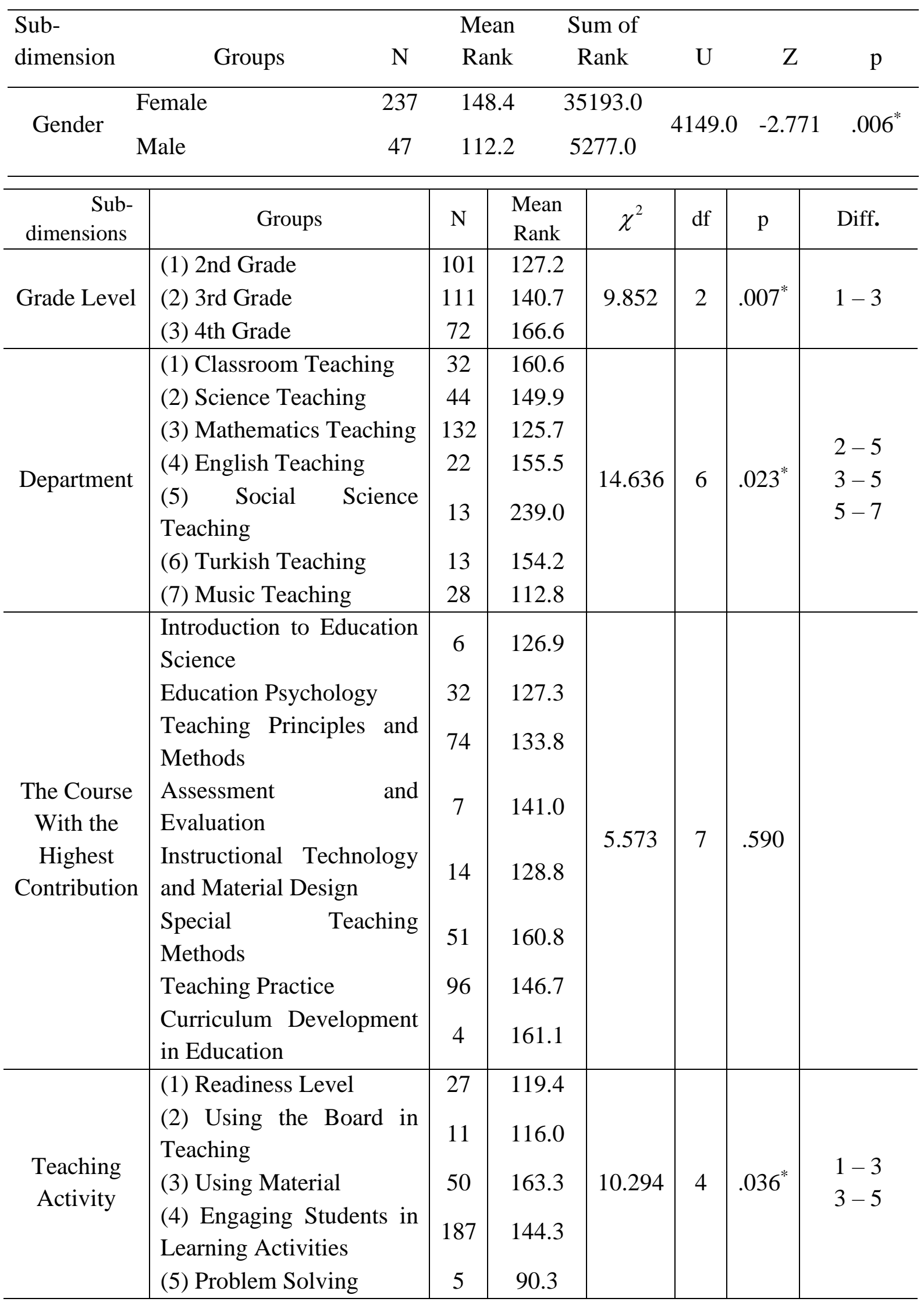

*the significance level is taken as $\mathrm{p}<0.05$ 
The Significance Level of the Pre-service Teachers' Conceptions of Teaching and Learning According to the Variables Identified (The Sub-dimension of Traditional Approach)

From the data given in Table 5, it was intended to measure whether the sub-dimension of constructivist approach, which is one of the sub-dimensions of the Teaching and Learning Conceptions Questionnaire used in line with the intended aims of the research, significantly differed according to the variables identified.

Table 5. The Differentiation Level of the Pre-service Teachers' Constructivist Approach According to Variables Identified

\begin{tabular}{|c|c|c|c|c|c|c|c|}
\hline $\begin{array}{c}\text { Sub } \\
\text { Dimension }\end{array}$ & Groups & $\mathrm{N}$ & $\begin{array}{l}\text { Mean } \\
\text { Rank }\end{array}$ & $\begin{array}{l}\text { Sum of } \\
\text { Rank }\end{array}$ & $\mathrm{U}$ & $\mathrm{Z}$ & $\mathrm{P}$ \\
\hline \multirow{2}{*}{ Gender } & nale & 237 & 134.5 & 31898.0 & \multirow{2}{*}{3695.0} & \multirow{2}{*}{-3.646} & \multirow{2}{*}{.000} \\
\hline & & 47 & 182.3 & 8572.0 & & & \\
\hline & & & Sira Ort. & $\chi^{2}$ & df & $\mathrm{p}$ & Fark \\
\hline \multirow{3}{*}{ Grade Level } & (1) 2nd Grade & 101 & 143.1 & \multirow{3}{*}{6.247} & \multirow{3}{*}{2} & \multirow{3}{*}{$.044^{*}$} & \multirow{3}{*}{$2-3$} \\
\hline & (2) 3rd Grade & 111 & 154.3 & & & & \\
\hline & (3) 4th Grade & 72 & 123.3 & & & & \\
\hline \multirow{7}{*}{ Depratment } & $\begin{array}{l}\text { (1)Classroom } \\
\text { Teaching }\end{array}$ & 32 & 98.1 & \multirow{7}{*}{29.889} & \multirow{7}{*}{6} & \multirow{7}{*}{$.006^{*}$} & \multirow{7}{*}{$\begin{array}{l}1-2 \\
1-7 \\
3-7\end{array}$} \\
\hline & $\begin{array}{l}\text { (2)Science } \\
\text { Teaching }\end{array}$ & 44 & 165.4 & & & & \\
\hline & $\begin{array}{l}\text { (3) Mathematics } \\
\text { Teaching }\end{array}$ & 132 & 131.3 & & & & \\
\hline & $\begin{array}{l}\text { (4)English } \\
\text { Teaching }\end{array}$ & 22 & 114.5 & & & & \\
\hline & $\begin{array}{l}\text { (5)Social Science } \\
\text { Teaching }\end{array}$ & 13 & 104.0 & & & & \\
\hline & $\begin{array}{l}\text { (6)Turkish } \\
\text { Teaching }\end{array}$ & 13 & 120.8 & & & & \\
\hline & $\begin{array}{l}\text { (7)Music } \\
\text { Teaching }\end{array}$ & 28 & 190.9 & & & & \\
\hline $\begin{array}{l}\text { The Course } \\
\text { with the }\end{array}$ & $\begin{array}{l}\text { Introduction to } \\
\text { Education }\end{array}$ & 6 & 148.8 & 12.856 & 7 & .076 & \\
\hline
\end{tabular}




\begin{tabular}{|c|c|c|c|c|c|c|c|}
\hline \multirow{9}{*}{$\begin{array}{c}\text { Highest } \\
\text { Contribution }\end{array}$} & Science & & & & & & \\
\hline & $\begin{array}{l}\text { Education } \\
\text { Psychology }\end{array}$ & 32 & 116.4 & & & & \\
\hline & Teaching & 74 & & & & & \\
\hline & $\begin{array}{l}\text { Principles and } \\
\text { Methods }\end{array}$ & & 131.7 & & & & \\
\hline & $\begin{array}{l}\text { Assessment and } \\
\text { Evaluation }\end{array}$ & 7 & 184.6 & & & & \\
\hline & $\begin{array}{l}\text { Instructional } \\
\text { Technology and } \\
\text { Material Design }\end{array}$ & 14 & 120.7 & & & & \\
\hline & $\begin{array}{l}\text { Special Teaching } \\
\text { Methods }\end{array}$ & 51 & 142.7 & & & & \\
\hline & Teaching Practice & 96 & 160.7 & & & & \\
\hline & $\begin{array}{l}\text { Curriculum } \\
\text { Development in } \\
\text { Education }\end{array}$ & 4 & 106.2 & & & & \\
\hline \multirow{5}{*}{$\begin{array}{l}\text { Teaching } \\
\text { Activity }\end{array}$} & $\begin{array}{l}\text { (1) Readiness } \\
\text { Level }\end{array}$ & 27 & 138.9 & \multirow{5}{*}{14.072} & \multirow{5}{*}{4} & \multirow{5}{*}{$.007^{*}$} & \multirow{5}{*}{$\begin{array}{l}1-2 \\
2-3 \\
2-4\end{array}$} \\
\hline & $\begin{array}{l}\text { (2) Using the } \\
\text { Board in } \\
\text { Teaching }\end{array}$ & 11 & 225.6 & & & & \\
\hline & $\begin{array}{l}\text { (3) Using } \\
\text { Material }\end{array}$ & 50 & 143.7 & & & & \\
\hline & $\begin{array}{l}\text { (4) Engaging } \\
\text { Students in } \\
\text { Learning }\end{array}$ & 187 & 136.1 & & & & \\
\hline & $\begin{array}{l}\text { (5) Solving } \\
\text { Problems }\end{array}$ & 9 & 177.9 & & & & \\
\hline
\end{tabular}

* The significance level is taken as $\mathrm{p}<0.05$

Table 5 indicates that the gender, grade level, department and teaching activity independent variables had a significant effect on pre-service teachers' traditional conceptions of teaching and learning whereas the variable of "the course with the highest contribution" did not show any significant effect. 
Looking at the gender variable first, it is seen that the mean rank of the male preservice teachers 182.3 (U: $3695.0 ; \mathrm{Z}:-3.646)$ are higher than the mean rank of the female pre-service teachers 134.5 (U: 3695.0; Z: -3.646). It can thus be implied that the male preservice teachers are more inclined to adopt a traditional approach than female pre-service teachers in terms of their conceptions of teaching.

A significant difference was also found in the grade level variable. However, since there are more than 2 sub-groups in the variable, Kruskall Wallis analysis was followed by Tamhane post hoc test whereby it was intended to identify significant differences between groups. As a result, significant difference was found between the 3rd graders and the 4th graders. This difference is in favor of the 3rd graders.

Given the significance levels of the pre-service teachers' constructivist teaching conceptions according to the department variable, a significant difference at the level of 0.05 was found. In a similar vein, following the Dunnet $\mathrm{C}$ post hoc test conducted, significant differences were found between 3 different sub-groups. Accordingly, significant differences were found between Science Teaching and Classroom Teaching which is in favor of Science Teaching. Another significant difference was found between Classroom Teaching and Music Teaching which is in favor of Music Teaching and lastly a significant difference was found between Music Teaching and Mathematics Teaching which is in favor of Music Teaching.

Given the significance levels of the pre-service teachers' constructivist teaching conceptions according to the department variable, a significant difference at the level of 0.05 was found. In a similar vein, following the Dunnet $\mathrm{C}$ post hoc test conducted, significant differences were found between 3 different sub-groups. Accordingly, significant differences were found between Science Teaching and Classroom Teaching which is in favor of Science Teaching. Another significant difference was found between Classroom Teaching and Music Teaching which is in favor of Music Teaching and lastly a significant difference was found between Music Teaching and Mathematics Teaching which is in favor of Music Teaching.

\section{An Investigation of the Pre-service Teachers' Metaphorical Perceptions about Their Teaching and Learning Conceptions}

The second sub-problem seeks to answer to the question of "Which metaphors do preservice teachers produce to explain their constructivist teaching approach?" To this end, the pre-service teachers were asked to fill in the gaps in the sentence of "Teacher is like......... Because......." according to their own perceptions. 
N. C. Dedebali \& S. Süral / Pamukkale University Journal of Education, 54, 158-187, 2022

Table 6. Metaphors Produced by the Pre-service Teachers to Explain Their Teaching and Learning Conceptions

\begin{tabular}{|c|c|c|c|c|c|}
\hline & $\begin{array}{l}\text { Metaphor } \quad- \\
\text { Frequency }\end{array}$ & No & $\begin{array}{l}\text { Metaphor } \\
\text { Frequency }\end{array}$ & No & Metaphor- Frequency \\
\hline 1 & Light - (f: 19) & 28 & Example (f: 2) & 55 & Life Changer \\
\hline 2 & Guide - (f: 17) & 29 & Google (f: 2) & 56 & Material \\
\hline 3 & Compass - (f: 16) & 30 & Route (f: 6) & 57 & Jigsaw \\
\hline 4 & Sun - (f: 16) & 31 & $\begin{array}{l}\text { Snow } \quad \text { Blower } \\
(\mathrm{f}: 2)\end{array}$ & 58 & Shooter \\
\hline 5 & Candle - (f: 13) & 32 & Leader (f: 5) & 59 & Construction Foreman \\
\hline 6 & Water - (f: 13) & 33 & Wise (f: 4) & 60 & Well \\
\hline 7 & Book-(f: 17) & 34 & $\begin{array}{l}\text { Raw Meatball (f: } \\
\text { 2) }\end{array}$ & 61 & Stairs \\
\hline 8 & Guiding - (f: 9) & 35 & Guide (f: 2) & 62 & Space \\
\hline 9 & Mother - (f: 9) & 36 & Technology (f: 2) & 63 & Heart \\
\hline 10 & Family - (f: 8) & 37 & Ocean (f: 2) & 64 & Student \\
\hline 11 & Gardener - (f: 7) & 38 & Mountain & 65 & Map \\
\hline 12 & North Star - (f: 6) & 39 & Salt & 66 & Wallet \\
\hline 13 & Lighthouse - (f: 6) & 40 & House & 67 & Rain \\
\hline 14 & Mirror - (f: 6) & 41 & Enlighted Person & 68 & Main Course Ingredient \\
\hline 15 & Tree - (f: 5) & 42 & Innovator & 69 & Fruit Tree \\
\hline 16 & $\begin{array}{l}\text { Traffic Sign - (f: } \\
\text { 4) }\end{array}$ & 43 & Liver & 70 & Neuron \\
\hline 17 & Road - (f: 4) & 44 & Vehicle & 71 & Rainbow \\
\hline 18 & Flower - (f: 3) & 45 & Open Buffet & 72 & Magnet \\
\hline 19 & Role Model - (3) & 46 & Pick & 73 & Chef \\
\hline 20 & Torch - (f: 3) & 47 & Corona Virus & 74 & River bed \\
\hline 21 & Gold - (f: 4) & 48 & User Guide & 75 & Factory \\
\hline 22 & $\begin{array}{l}\text { Source of } \\
\text { Information - (f: } \\
3 \text { ) }\end{array}$ & 49 & Medicine - (f: 3) & 76 & Forest \\
\hline 23 & Friend - (f: 8) & 50 & Treasure & 77 & Building \\
\hline 24 & Sea - (f: 3) & 51 & Soil & 78 & Hero \\
\hline 25 & Engineer - (f: 5) & 52 & Answer Key & 79 & Knowledge Transmitter \\
\hline 26 & Explorer (f: 2) & 53 & Captain & & \\
\hline
\end{tabular}


After the data were obtained, they were divided into separate categories by both researchers and the frequency values of each category were determined and tabulated, and then sample sentences regarding the categories were presented.

When Table 6 is examined, it is seen that the most repeated metaphors that preservice teachers used to explain their conceptions of learning and teaching were "light (f:19)", followed by "guide (f:17)", "book (f17)", "compass (f:16)". )", “sun (f: 16)", “candle (f: 13)", "water (f13)". In general, it can be interpreted that the pre-service teachers reported concrete facts as well as abstract concepts in their metaphors. In a broad sense, given that the 79 different metaphors produced by the pre-service teachers, it is understood that the preservice teachers developed different perspectives towards the concept of teacher.

When the metaphors developed by pre-service teachers were analyzed, the metaphors produced were grouped into the categories such as facilitating life, professional and human roles, what nature offers, useful goods, and what are found in the organism.

Table 8. Frequency Values of Categories Obtained from Metaphor Analysis

\begin{tabular}{l|l|c}
\hline \multicolumn{1}{|c|}{ Categories } & Frequency Values \\
\hline$\square$ & Facilitating life & 149 \\
\hline & Professional and Human Roles & 32 \\
\hline & What Nature Offers & 54 \\
\hline & Useful Goods & 45 \\
\hline & What Are Found In The Organism & 4 \\
\hline
\end{tabular}

In the category of "Facilitating Life ", the participants mostly produced metaphors such as guiding, guide and facilitating life for students. For example, a pre-service teacher (T6) reported, "It is like a road because we discover ourselves by discovering." Another preservice teacher (T41) stated, "It is like a lighthouse, it sheds light on the future."

Given the category of "Professional and Human Roles", the pre-service teachers associated teachers with different professions characterizing the teacher as someone who has different characteristics. Accordingly, while a pre-service teacher (T54) commented, "Because the captain helps the students reach their goal and find the right paths in that process", another pre-service teacher (T135) produced a metaphor related to the concept of teacher stating that, "He is like a gardener because if each student is a flower, s/he knows their needs and prepares a suitable environment for them to grow." 
In the category named as "What Nature Offers", it can be implied that pre-service teachers attribute a meaning to the teacher considering the facts and events that nature raises and gives life to human beings with its existence. As an opponent of this idea, the preservice teacher (T128) stated, "A teacher is like a tree, because every student s/he will raise will be fruitful fruit for the future". Another pre-service teacher (T165) also support the category identified reporting that "It is like space. It contains every kind and all of the variety of life."

In the category of "Useful Goods", it was observed that the pre-service teachers attributed different metaphors to the teacher from a pragmatist point of view. Thus, preservice teachers reported that just as useful goods help humans in life, so the teacher helps his/her students a lot. In this context, one of the pre-service teachers (T205) said that "teacher is like a building and students are like those living in the building, if the base of the building is weak, it will collapse at the slightest shake”. Another pre-service teacher (T227) explained the category as follows: "A teacher is like a snow blower, he/she clears the way to modernity."

The last category called "What Are Found in the Organism" emerged as a result of the metaphors produced by the pre-service teachers. The pre-service teachers might associate the assumed roles of teachers with everything in the human body. From this point of view, a pre-service teacher (T239) stated, "Teacher is like a heart because it manages the whole class." Another pre-service teacher (T14) commented, "Like a coronavirus; because it is contagious just like the effect it leaves on people. And s/he makes those who do not want to learn, that is, those with low immunity, or those who make excuses for being wise, that is, chronic patients, return to inner world and become aware of the facts." The use of such expressions thus supports the opinion of the researchers.

\section{Comparison of Metaphors Determined by Levels of Teaching and Learning Conceptions}

The third and last sub-problem of the research seeks to answer to the question of "Do the pre-service teachers' metaphors of constructive learning differ according to their conceptions of teaching and learning? "and the pre-service teachers' scores on their conceptions of teaching and learning were sequenced from greatest to lowest. Afterward, the pre-service teachers' metaphor scores in the upper $27 \%$ group and the scores in the lower $27 \%$ groups were compared. Considering that there were a total of 284 pre-service teachers 
in the research sample, the number of people included in the comparison of the scores in the lower $27 \%$ and upper $27 \%$ groups was determined as 77 .

Table 7. Frequency Distribution of the Metaphors Attributed to the Teachers by the Preservice Teachers According to their Conceptions of Teaching and Learning

\begin{tabular}{l|c|c|c|c}
\hline \multirow{2}{*}{} & \multicolumn{4}{|c}{ Levels of Learning and Teaching Conceptions } \\
\cline { 2 - 5 } & Upper $27 \%$ group & \multicolumn{2}{c}{ Lower 27\% group } \\
\cline { 2 - 5 } & $\mathrm{f}$ & $\%$ & $\mathrm{f}$ & $\%$ \\
\hline Facilitating Life & 41 & 14.3 & 7 & 2.4 \\
\hline Professional and Human Roles & 8 & 2.8 & 17 & 6.0 \\
\hline What Nature Offers & 25 & 8.7 & 19 & 6.7 \\
\hline Useful Goods & 3 & 1.2 & 33 & 11.5 \\
\hline What are Found in Organism & - & 0 & 1 & 0.4 \\
\hline TOTAL & 77 & 27 & 77 & 27 \\
\hline
\end{tabular}

When Table 7 is examined, the most repeated metaphor in the upper $27 \%$ group is facilitating life (f: 41), no metaphor is found in the category of what are found in the organism. When the frequency distribution of the metaphors produced by the 77 pre-service teachers who have the lowest learning-teaching conception scores is examined, it is seen that there is an accumulation in the useful goods (f: 33) category, the frequency distributions of the category of professional and human roles (f: 17) and the category of what nature offers (f: 19) are close to each other. As indicated in Table 7, the category of "what are found in the organism", which has no frequency value in the upper $27 \%$ group, revealed one metaphor.

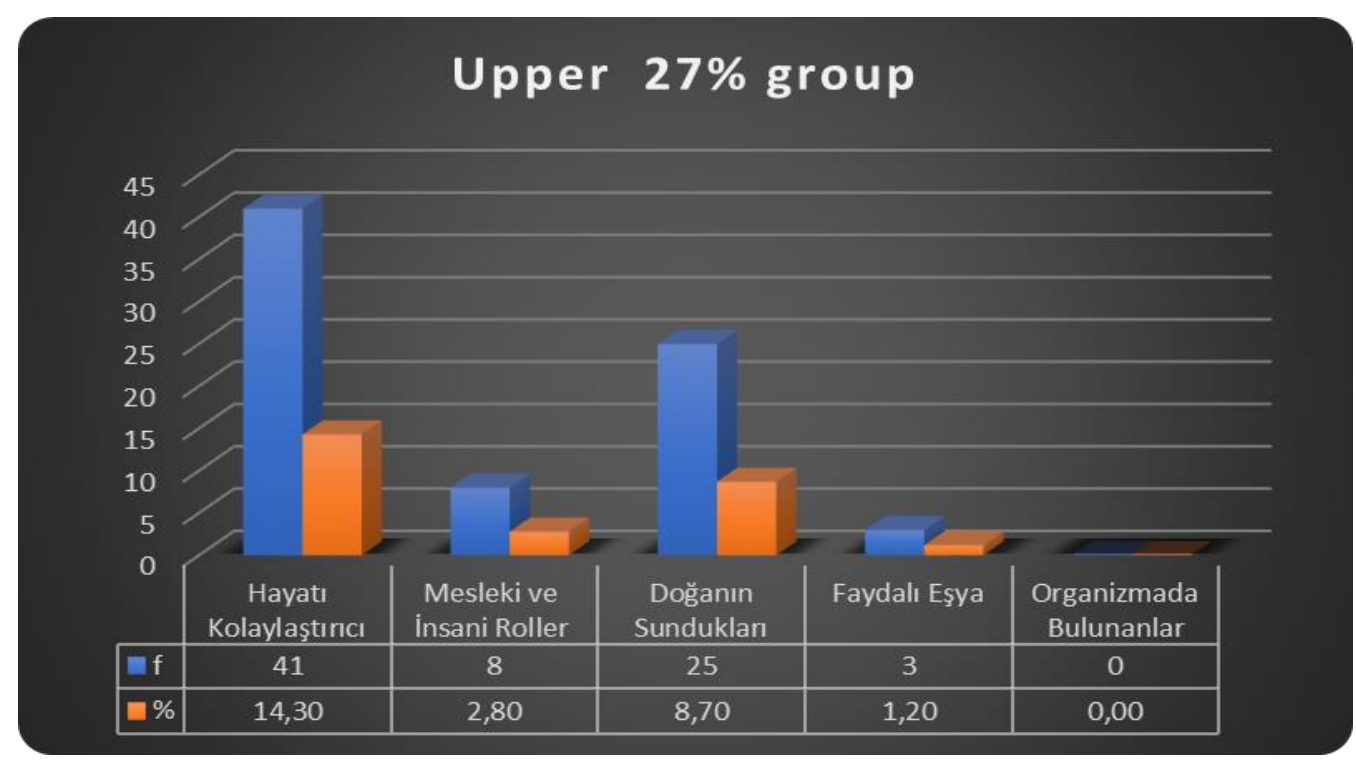




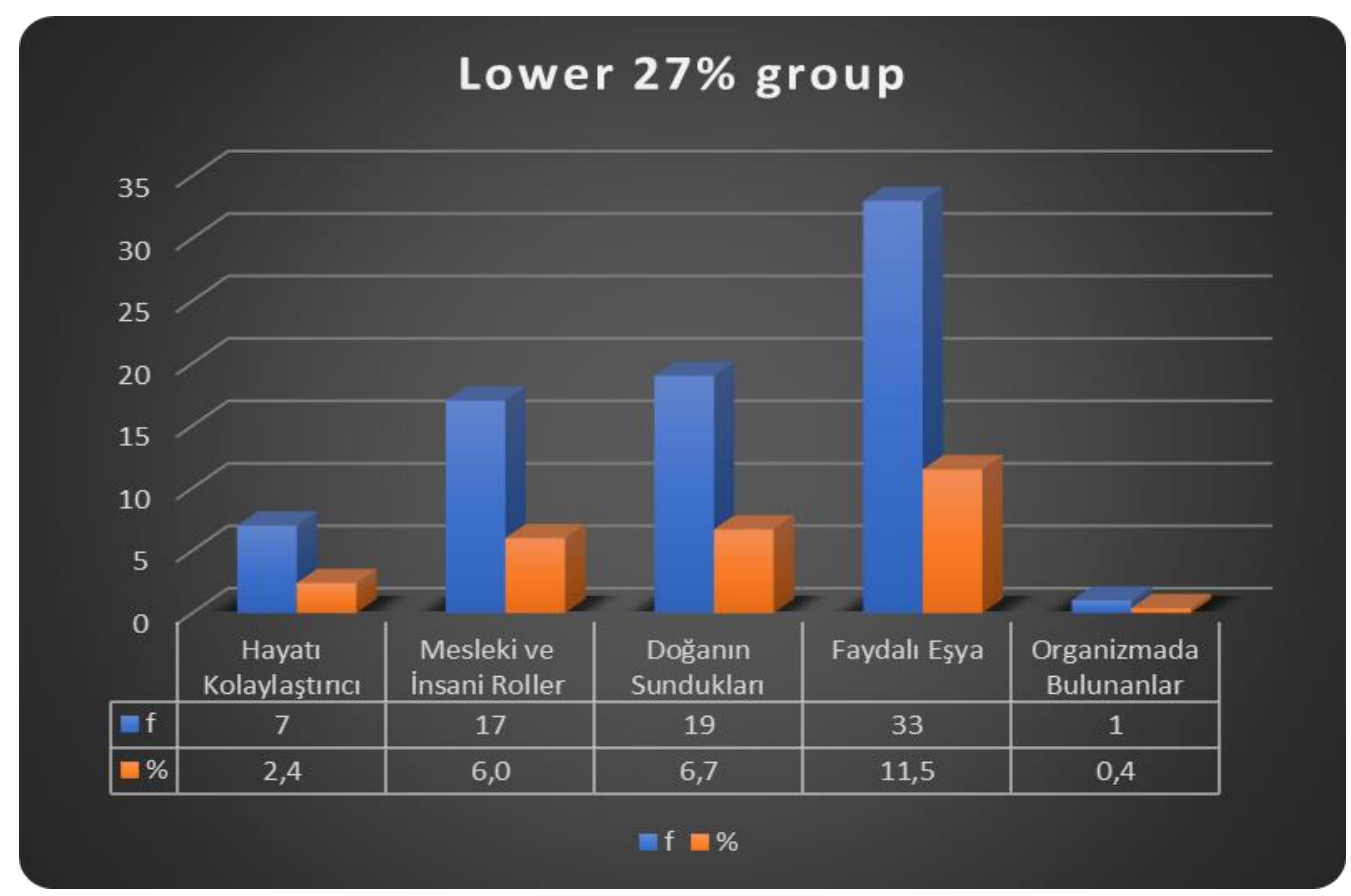

Figure 2. Bar Chart for the Distribution of the Metaphors in the Lower 27\% Group

\section{Discussion, Result and Suggestions}

This study aimed to determine the levels of learning and teaching conceptions and metaphorical perceptions of pre-service teachers studying at faculties of education. According to the data obtained in the research, it can be concluded that the learning and teaching conceptions of the students in the study group reflects the constructivist approach more than the traditional approach. This result might be because faculties of education take constructivist approach as a basis in the development and implementation of curriculum. In addition to that, it can be considered as a reflection of educational reforms based on the constructivist approach that has been applied to the Turkish Education System for 15 years.

In line with the sub-objectives of the research, while the variables of gender, grade level, department and teaching activity yielded a significant difference on the constructivist learning-teaching conceptions of the pre-service teachers, it was seen that the variable of "the course with the highest contribution" did not show a significant effect. When the arithmetic mean of the groups in the gender variable are examined, it is seen that the teaching and learning conceptions of female pre-service teachers is more suitable for constructivism compared to male pre-service teachers. These results obtained in the gender variable in the sub-dimension of pre-service teachers' conceptions of teaching and learning are consistent with earlier reports in the literature (Aypay, 2011; Oğuz, 2011; Baş, 2014). 
The fact that female pre-service teachers have adopted a more constructivist teaching approach can be explained by the socio-cultural environment of individuals' perspective on gender and educational experiences in the family. However, when the relevant literature is examined, no significant gender difference was observed with respect to the pre-service teachers' conceptions of teaching and learning (Bağc1, 2019; Yaral1, 2019; Bilgin \& Aykac, 2016; Engin \& Daşdemir, 2015).

According to the findings obtained by the research, it is seen that the level of constructivist teaching approach increases as the grade level increases. There is a significant difference in favor of the fourth-grade pre-service teachers. A review of several studies conducted with pre-service teachers in the literature reveals that as the grade level increases, learning and teaching approaches significantly differ (B1kmaz, 2017; Löfström \& PoomValickis, 2013; Tang et al., 2012). The main source of this difference can be explained by the contribution of the development and implementation of constructivist-based curricula in faculties of education to the learning and teaching conceptions of pre-service teachers. As a matter of fact, it can be expected that the teaching practice courses in the last years of the faculty of education will lead to a change in teaching and learning conceptions of pre-service teachers.

In the study, a significant difference was found in the teaching and learning conceptions according to the department variable. As a result of the analyses conducted to reveal the source of the differentiation, it was understood that the pre-service teachers studying in the social studies department also are more tended to adopt the constructivist approach. Further, when the mean of the pre-service teachers were examined in terms of department variable, it was seen that the levels of teaching and learning conceptions of the pre-service teachers studying in Turkish, classroom and science teaching programs were found to be higher. Furthermore, in a study conducted by Oğuz (2011) it was observed that social studies pre-service teachers adopt a more constructivist teaching-learning approach than science pre-service teachers. In a similar vein, in a study carried out in two parts, it was concluded that pre-service primary school teachers had a more constructivist learningteaching approach than pre-service science teachers.

The results denoted that the variable of the course with the highest contribution did not make a significant difference. In addition, it can be argued that the contribution mean of all the courses covering the teaching profession knowledge in the research is at a high level. According to the study conducted by Süral (2011) with primary pre-service teachers, 
teaching profession knowledge courses are considered as the most necessary courses by preservice teachers which supports the results of the present study.

While there was a significant difference in favor of "using material" in regards to the findings of constructivist learning and teaching approaches in the context of teaching activity, a significant difference was found in favor of "using the board in teaching" regarding the traditional teaching and learning approach. Depending on the changing living conditions, the emerging needs have been very effective on the teaching and learning conceptions of the teacher. It can be asserted that pre-service teachers paid a close attention to use materials so that they can help students engage in the lesson and enhance clarity in learning in a constructivist learning-teaching approach.

The pre-service teachers who participated in the research produced a total of 278 metaphors, 79 of which were different, to explain their perceptions of the constructivist teacher. It was revealed that pre-service teachers emphasized different aspects of the concept of constructivist teacher through metaphors they generated. The most frequently repeated metaphors were determined as light, guide, book, compass, sun, candle, water. Metaphors produced in this study, such as compass, sun, light, navigation, and book, were similarly produced in Y1ldiz's (2019) metaphor study with pre-service teachers on the constructivist teacher. In addition to that, given the metaphor studies in the literature examining the concept of teacher, it is seen that there are various studies that are similar to the metaphors produced in this study. Similarly, in Kiral's (2015) study with pre-service teachers, metaphors such as guide, compass, parent, sun, candle, pole star were produced for the concept of teacher. Furthermore, in Pehlivan's (2010) research, while the concept of teacher was mostly expressed by metaphors such as sun, parent, light, lighthouse, compass, in Ertürk's (2017) study with primary school students, the concept of teacher was expressed with similar metaphors such as mother, father, sun, bee, lighthouse, compass, and pole star. The present study and similar previous metaphor studies in the literature place emphasis on the guiding role of the teacher.

In the light of the data obtained, the metaphors produced by pre-service teachers were categorized under the common headings of "facilitating life ", "professional and human roles", "what nature offers", "and useful goods" and "what are found in the organism". Likewise, in a study conducted by Y1ldiz (2019), 10 categories were formed from the metaphors that the students produced about Constructivist Teacher. These categories are: Guiding / Enlightening Teacher, Caring Teacher, Affectionate and Compassionate Teacher, 
Information Source and Transmitter Teacher, Problem Solver and Leader Teacher, Autonomy Supporting and Controlling Teacher, Master Teacher, Teacher Supporting Meaningful Learning and Thinking, Life Source Teacher, The Teacher Who Provides Peace with Its Presence, The Teacher Who Reveals Original Things. In the study conducted by Eren and Tekinarslan (2013) with pre-service teachers, the teacher concept was defined through three categories such as "Teacher as a loving and caring person", "Teacher as a source of knowledge", and "Teacher as a guide".

Given the data obtained from the pre-service teachers, the constructivist teacher mostly is associated with the expression of "facilitating life". The metaphors of light, guide, compass, candle, guiding, mother, family, north star, lighthouse, traffic sign were produced by the pre-service teachers in the category of facilitating life. The constructivist teacher is described as a person who does not present the true knowledge to the students in the learning processes; guides students to reach the true knowledge rather than transferring the knowledge; considers the differences of the students when planning activities, and believes in the realm of learning by doing and experiencing which maximizes learning retention.

In the study of Küçüktepe and Gürültü (2014), the constructivist teacher was expressed as a person who adopts a student-centered approach in class activities and the idea of learning by doing in permanent learning and who is aware of the differences between individuals, guides the student in learning and mentors the student any time. These results are consistent with the research results of Yildiz (2019), Ocak and Gündüz (2006), Tuan, Chang, Wang, and Treagust (2000). Given these metaphors obtained in the category of facilitating life, it can be concluded that pre-service teachers perceive the concept of constructivist teacher very well.

In the category of professional and human roles, metaphors such as gardener, friend, engineer, innovator, construction foreman, explorer and fellow were produced. Considering the metaphors developed by the pre-service teachers in this category, it can be argued that the constructivist teacher is seen as a shaper who shapes the learning process, organizes materials suitable for learning and teaching processes and plans learning activities related to students' interests and wishes. Özden (2003) posited that the learning process challenges students to address real-world problems whereby students learn. According to Küçüktepe (2003), the role of the teacher in constructivist philosophy is not to provide information, but to provide new opportunities and motivation to the student in the process of constructing 
knowledge. From the metaphors obtained in the research, it was understood that the preservice teachers perceived the role of the teacher in the process of preparing students for life.

In the category of what nature offers, metaphors such as sun, water, gold, flower, tree, sea, soil, ocean and mountain were generated. The fact that pre-service teachers produced metaphors related to essential substances for life in nature, such as sun, water, gold might imply that pre-service teachers attach special importance to the teaching profession. In a study conducted by Yılmaz, Göçen, and Yılmaz (2013) with pre-service teachers, the results revealed that teaching is not seen as a respected profession. Furthermore, considerable research put forwards that teaching is viewed as a profession that everyone can do due to the poor socio-economic status of teachers (Celep, 2004; Ceylan, 2001). It is however worth noting that the value placed on teacher is the clear indicator of the value placed on education.

Lastly, it was intended to examine the relationship between the learning-teaching conceptions of the pre-service teachers and the metaphor they developed regarding the concept of constructivist teacher. To this end, the pre-service teachers' metaphor scores in the upper $27 \%$ group and the scores in the lower $27 \%$ groups were compared. It was found that the pre-service teachers with the highest learning-teaching conceptions scores used the metaphors in the category of facilitating life to explain the constructivist teacher. Given that the individuals can use the knowledge they acquire in daily life and transform the knowledge into a skill, as stated in the pragmatist movement, which is the basic philosophy on which the constructivist education approach is based, which is also stated in the main purpose of the research, it can be suggested that pre-service teachers with a high level of learning and teaching conceptions comprehend this basic philosophy formulated by pragmatist thinking. As a result, considering the fact that the right information is information that benefits human beings, the pre-service teachers grasp the constructivist learning approach, and they perceive being a teacher who makes life easier for their students and express this metaphorically in the research. The pre-service teachers with the lowest learning-teaching conceptions developed metaphors in the category of useful goods. Therefore, it can be said that preservice teachers with a high level of learning and teaching conceptions perceive the concept of teacher more as a guide and light. From a different perspective, it can be stated that students with low level of teaching and learning conceptions perceive the concept of teacher in terms of the benefit the teacher provides to the student. 
To conclude, both the pre-service teachers with a high level of learning and teaching conceptions and the pre-service teachers with a low level of learning and teaching conceptions produced metaphors related to constructivist approach. In this context, it can be argued that the teaching and learning conceptions of the pre-service teachers and the metaphors they developed regarding the concept of constructivist teacher reveal important results in terms of understanding their perceptions of teaching in the future. Since the preservice teachers' perceptions of teaching profession will undoubtedly impact their future learning and teaching perceptions, it increases the importance of the matter one more time. Further metaphorical studies can dwell upon the change in the meanings that pre-service teachers attribute to the constructivist teacher at different times. Likewise, a similar study, which aims to determine the level of teaching and learning conceptions and metaphorical perceptions of pre-service teachers, can be conducted with teachers from different departments and grade level so that their perceptions and metaphors regarding the preservice and in-service teaching can be compared. Thus, an in-depth research on teaching profession can be implemented whereby data from wider participants can be collected and findings can be generalized.

Ethics Committee Permission Information: In this section This research was conducted with the permission obtained with the decision of the Social and Human Sciences Scientific Research and Publication Ethics Committee dated 10/02/2021 and numbered 68282350/2018/G03.

\section{Author Conflict of Interest Information}

There was no conflict of interest between the authors during the research process.

\section{Author Contribution}

The first author of the study, Assoc. Dr. Nurhak Cem DEDEBALI contributed to the data collection part of the research, determining the purpose of the research and managing the process. In addition, the author wrote the discussion, conclusion and recommendations part of the research.

The second author of the study, Assoc. Dr. Serhat SÜRAL contributed to the data collection part of the research, determining the purpose of the research and managing the process. In addition, the author wrote the introduction, method and findings sections of the research. 


\section{References}

Akar, H. \& Yıldırım, A (2004). Oluşturmacı öğretim etkinliklerinin sınıf yönetimi dersi'nde kullanılması: bir eylem araştırması, İyi Örnekler Konferansı, 1 -15, İstanbul.

Arslan, M. M. \& Bayrakçı, M. (2006). Metaforik düşünme ve öğrenme yaklaşımının eğitimöğretim açısından incelenmesi. Milli Eğitim Dergisi, 35(171), 100-108.

Aydın, H. (2007). Felsefi temelleri işığında yapılandırmacılık, Ankara: Nobel Yayın.

Aydın, S. İ. \& Pehlivan, A. (2010). Türkçe öğretmeni adaylarının “öğretmen” ve "öğrenci” kavramlarına ilişkin kullandıkları metaforlar. International Periodical For the Languages, Literature and History of Turkish 5(3) 818-842.

Aypay, A. (2011). Öğretme ve öğrenme anlayışları ölçeği’nin Türkçe uyarlaması ve epistemolojik inançlar ile öğretme ve öğrenme anlayışları arasındaki ilişki. Kuram ve Uygulamada Ĕ̈itim Bilimleri, 11(1), 7-29.

Bağcı, H. (2019). İlköğretim matematik öğretmeni adaylarının öğretme-öğrenme anlayışları ile teknopedagojik eğitim yeterlikleri arasındaki ilişki. Pesa International Journal of Social Studies, 5(1), 1-9.

Bakır, K. (2006). Pragmatizm ve eğitime yansımaları. Atatürk Üniversitesi Kazım Karabekir Ĕ̈itim Fakültesi Dergisi, (14), 49-68.

Baki, A. \& Gökçek, T. (2012). Karma Yöntem Araştırmalarına Genel Bir Bakış. Elektronik Sosyal Bilimler Dergisi, 11(42), 1-21.

Baş, G. (2014). İlköğretim öğretmenlerinin öğrenme öğretme anlayışlarının bazı değişkenler açısından değerlendirilmesi. Dicle Üniversitesi Ziya Gökalp Eğitim Fakültesi Dergisi, (22), 18-30.

Bıkmaz, F. (2017). Öğretmen adaylarının öğretme-öğrenme anlayışları ve bilimsel epistemolojik inançlarının araştırılması: Boylamsal bir çalışma. Eğitim ve Bilim, 189, 183-196.

Bilgin, H. \& Aykac, N. (2016). Pre-Service teachers' teaching-learning conceptions and their attitudes towards teaching profession. Educational Process: International Journal, 5(2), 139-151. 
Can, Ş. \& Çelik, C. (2018). Fen bilgisi ve sınıf öğretmeni adaylarının öğretme-öğrenme anlayışlarının incelenmesi. Afyon Kocatepe Üniversitesi Sosyal Bilimler Dergisi, 20 (1), 327-339.

Creswell, J. W. (2003). Research design: Qualitative, quantitative, and mixed methods approaches (2nd ed.). Thousand Oaks, CA: Sage.

Değermencioğlu, Ç. (2000). Ĕ̆itimin felsefi temelleri: ĕ̆itim felsefe ilişkisi: eğitim felsefesi. L. Küçükahmet (Ed.), Öğretmenlik Mesleğine Giriş (3. Baskı) İçinde (S. 81-96). Ankara: Nobel Yayın Dağıtım.

Demirel, Ö. (2008). Yapılandırmacı Eğitim. Ĕ̆itim ve Öğretimde Çă̆daş Yaklaşımlar Seтровуити, 03-04 Nisan 2008. İstanbul: Harp Akademileri Basımevi.

Draaisma, D. (2000). Metaphors of memory: A history of ideas about the mind. Cambridge University Press.

Engin, G. \& Daşdemir, İ. (2015). Sınıf öğretmenlerinin öğretme ve öğrenme anlayışlarının çeşitli değişkenler açısından incelenmesi. The Journal of Academic Social Sciences Studies, (33), 425-432.

Eren, A. \& Tekinarslan, E. (2013). Öğretmen, öğretme, öğrenme, öğretim materyali ve değerlendirmeye ilişkin metaforlar: Yapısal bir analiz. Gaziantep University Journal of Social Sciences, 12(3), 443-467.

Ertürk, R. (2017). İlkokul öğrencilerinin “öğretmen” kavramına ilişkin metaforik algıları. EUluslararası Eğitim Araştırmaları Dergisi, 8(3), 1-15.

Fer, S. \& Cırık, İ. (2007). Yapılandırmacı öğrenme-kuramdan uygulamaya. İstanbul: Morpa Yayınları.

Gall, J. P., Gall, M. D. \& Borg, W. R. (1999). Applying educational research: A practical guide. Longman Publishing Group.

Göğebakan Yıldız, D. (2017). Eğitimde program geliştirme dersine yönelik tutum ve metaforik algıların incelenmesi. 4. Uluslararası Ĕ̆itim Programları ve Öğretim Kongresi.

Kazu, H. (2002). Ĕgitim ve Felsefe. M. Taşpınar (Ed.), Öğretmenlik Mesleği İçinde (S.6482). Elazığg: Elazı ̆̆ Üniversitesi Yayınevi. 
N. C. Dedebali \& S. Süral / Pamukkale University Journal of Education, 54, 158-187, 2022

Kıral, E. (2015). Öğretmen adaylarının algılarına göre öğretmen metaforları. Adnan Menderes Üniversitesi Ĕ̆itim Fakültesi Eğitim Bilimleri Dergisi, 6(1), 57-65.

Küçüktepe, C. (2003). Pedagojik konstruktivist etkinliklerle işlenen derslerin eleştirel düşünmeye ve kalıcılı̆̆a etkisi. Yayınlanmamış Doktora Tezi, Abant İzzet Baysal Üniversitesi, Sosyal Bilimler Enstitüsü, Bolu.

Küçüktepe, S. E. \& Gürültü, E. (2014). Öğretmenlerin" yapılandırmacı öğretmen" kavramına ilişkin algılarına yönelik metafor çalışması örneği. Abant İzzet Baysal Üniversitesi Eğitim Fakültesi Dergisi.

Lakoff, G. \& Johnson M. (2005). Metaforlar hayat anlam ve dil (Çeviren: Gökhan Yavuz Demir). İstanbul: Paradigma Yayıncılık.

Löfström, E. \& Poom-Valickis, K. (2013). Beliefs about teaching: persistent or malleable? A longitudinal study of prospective teachers' beliefs. Teaching and Teacher Education, (35), 104-113.

Marlowe, B. A. \& Page, M. L. (2005). Creating and sustaining the constructivist classroom. Corwin Press.

Morgan G. (1998). Yönetim ve örgüt teorilerinde metafor (Çev. G. Bulut). İstanbul: BZD Yayınc1lik.

Ocak, G. \& Gündüz, M. (2006). Eğitim fakültesini yeni kazanan öğretmen adaylarının öğretmenlik mesleğine giriş dersini almadan önce ve aldıktan sonra öğretmenlik mesleği hakkındaki metaforlarının karşılaştırılması. Afyon Kocatepe Üniversitesi Sosyal Bilimler Dergisi, 8(2), 293- 310.

Oğuz, A. (2011). Öğretmen adaylarının demokratik değerleri ile öğretme ve öğrenme anlayışlarının incelenmesi. Değerler Eğitimi Dergisi, 9(22), 139-160.

Ögülmüş, S. (1991). İçerik analizi. Ankara Üniversitesi Eğitim Bilimleri Fakültesi Dergisi, 24(1), 213-228.

Özden, Y. (2003). Öğrenme ve Öğretme. Ankara:Pegem Yayınları.

Perkins, D. (1999). The Many Faces Of Constructivism. Educational Leadership, 57(3), 611. 
Saban, A, Koçbeker, B. N. \& Saban A. (2006). Öğretmen adaylarının öğretmen kavramına ilişkin algılarının metafor analizi yoluyla incelenmesi. Kuram ve Uygulamada Ĕgitim Bilimleri, 6(2), 461-522.

Saban, A. (2008). Okula ilişkin metaforlar. Kuram ve Uygulamada Eğitim Yönetimi. 55, 459-496.

Saban, A. (2004). Giriş düzeyindeki sınıf öğretmeni adaylarının öğretmen kavramına ilişkinileri sürdükleri metaforlar. Türk Eğitim Bilimleri Dergisi, (2), 135-155.

Süral, S. (2015). Sınıf öğretmenliği öğretmen adaylarının öğretmen yetiştirme programındaki derslerin gerekliliği ve işe vurukluk düzeyleri hakkındaki görüşleri. Trakya Üniversitesi Ĕ̈itim Fakültesi Dergisi, 5(1), 34-43.

Şaşan, H. H. (2002). Yapılandırmacı öğrenme yaklaşımı. Yaşadıkça Eğitim. 74(75), 49-52.

Tanberkan, H. (2015). İçerik Analizinde Geçerlik ve Güvenirlik, [Çevrimiçi: https://prezi. com/yrhdpwinv3a/icerik-analizinde-gecerlik-ve-guvenirlik/]. Erişim Tarihi, 23.

Tang, S. Y. F., Wong, A. K. Y. \& Cheng, M. M. H. (2012). Professional learning in initial teacher education: Vision in the constructivist conception of teaching and learning. Journal of Education for Teaching: International Research and Pedagogy, 38(4), 435451.

Tuan, H. L., Chang, H. P., Wang, K. H., \& Treagust, D. F. (2000). The development of an instrument for assessing students' perceptions of teachers' knowledge. International Journal of Science Education. 22(4), 385-398.

Vadeboncoeur, J. A.; Torres M. N. (2003). Constructing and reconstructing teaching roles: a focus on generative metaphors and dichotomies. Discourse: Studies in the Cultural Politics of Education, 24(1), 87-103.

Wheatley, G.H. (1991). Constructivist perspectivest on sciences and mathematics learning. Science Education, 75(1), 9-21.

Yaralı, D. (2019). Öğretmen adaylarının öğrenme öğretme anlayışlarının çeşitli değişkenler açısından incelenmesi. Turkish Studies, 14(4), 2869-2887.

Yıldırım, A. \& Şimşek, H. (2008). Sosyal bilimlerde nitel araştırma teknikleri. Ankara, Turkey: Seçkin Yayınevi. 
N. C. Dedebali \& S. Süral / Pamukkale University Journal of Education, 54, 158-187, 2022

Yıldız, H. (2019). Öğretmen adaylarının yapılandırmacı öğretmen ve sınıf ortamına yönelik görüşlerinin metafor analizi ile incelenmesi. Turkish Studies, 14(4), 1971-1994.

Yurdakul, B. (2005). Yapılandırmacılık. Demirel, Özcan (Editör), Eğitimde Yeni Yönelimler, Pegem A Yayınc1lı, Ankara: (39- 61). 